Мариел Чернь

АН Чешской республики, Прага

\title{
Франтишек Рут Тихий - выдающийся пропагандист белорусского языка и литературы межвоенного периода в Чехословакии
}

Имя Франтишека Рута Тихого (на чешском František Rut Tichý) было в свое время хорошо известно и часто вспоминалось в кругах чешских и словацких германистов, богемистов и славистов, и не только в связи с популяризационной деятельностью, а скорее, в большей мере, с узко специализированными профессиональными и научными исследованиями, а также починами в области художественного перевода, в особенности поэтического. Сегодня о личности Франтишека Тихого хотя и упоминают иногда исследователи украинистики, болгаристики и словацистики, но в целом его деятельность, как и он сам, принадлежит к кругу полузабытых представителей поколения чешских деятелей культуры, широко ориентированных в направлении славянской культуры и глубоко эрудированных в этой области, живших и работавших в период примерно первых двух третей 20-го века. В этой статье я попытаюсь кратко вспомнить его заслуги в области белорусистики межвоенного периода (с некоторым переходом за пределы 1945 года), интерес к которой пробудился у него во время занятий украинистикой, когда судьба привела его в начале 20-го века в Подкарпатскую Русь вновь приобретённую территорию Чехословацкой республики.

\section{I. Биографический портрет Франтишека Рута Тихого}

Он родился 21 мая 1886 года в местечке Хинява у Бероуна (Средняя Чехия) в учительской семье (отец Франтишек Тихий, мать Ма- 
рия, урождённая Дондова); был крещён 3 июня в католической церкви и по имени Святого Франтишека Серафинского получил используемые им в молодости инициалы и фамилию - Ф. С. Тихий, но позже (в начале 1919) он перешёл в чешскобратскую веру евангелической церкви, и по истечении 1945 года его имя приобрело новое звучание - Франтишек Рут Тихий ${ }^{1}$ К Как он сам писал в своей недатированной автобиографии ${ }^{2}$, он прожил «прекрасное детство» в местечке Железна (также в районе города Бероун), где в 1889 году его отец стал руководящим учителем местной школы (этот пост сегодня соответствует примерно положению директора). Отец его был серьёзным и рассудительным, а мать энергичной, образованной и нежной женщиной. Несколько десятилетий она была промышленной учительницей (т.е. обучала ремесленничеству и другим бытовым навыкам). Десятилетний Франтишек приехал в Прагу в качестве вокалиста церковного хора на конвент Ордена Крестоносцев Красной Звезды, а вскоре начал посещать престижную Академическую гимназию, через которую прошёл целый ряд деятелей возрождения, дальнейших интеллектуалов и писателей. После окончания гимназии (1905) он начал обучение на философском факультете в Карловом университете.

Однако, несмотря на то, что отец не мог поддерживать сына материально, так как в это время заболел и был вынужден лечиться на курорте, Тихий остался после Рождества 1905 года дома и готовился к дополнительным экзаменам в Педагогическом институте. При этом он оставался записанным в университет и сразу после выпускного экзамена сдавал на факультете свой первый коллоквиум знаменитому писателю и профессору сравнительной истории литератур Ярославу Врхлицкому. В период с 1906 по 1909 годы он преподавал в общеобразовательных и мещанских школах «смиховского района» (сегодня это

1 В виде сканированного документа доступна для ознакомления метрическая запись о его рождении и крещении: http://ebadatelna.soapraha.cz/d/9912/138 [on-line 07-07-2016].

2 F. Tichý, Curriculum vitae, машинопись в объёме 4 стр., написанных, очевидно, в сентябре 1945 года в связи с заявлением о приёме на должность преподавателя средней школы во вновь открытой гимназии в г. Марианске Лазне (Западная Чехия), находится в несистематизированном до сих пор авторском наследии, фонд Tichý František, Литературный архив Памятника национальной письменности (Literární archiv Památníku národního písemnictví), Прага (далее фонд Тихий); там же находятся две автобиографии, которые я использую при уточнении (и дополнении) данных, имеющихся в Curriculu vitae, и при рассмотрении послевоенных событий: Автобиография [I.], недатированная машинопись, 2,5 стр., очевидно, 1952 г., и другая Автобиография [II.], недатированная машинопись, 2,5 стр., очевидно, 1965 г. 
часть Праги) и параллельно продолжал обучение в университете. В то время кандидат не должен был выбирать одну или две профессии, но записывался на лекции и по некоторым выбранным темам сдавал коллоквиум. Тихий выбирал преимущественно темы из области чешской и немецкой филологии с отдельными экскурсами в область славистики. Последний семестр (летний) 1909 года он провёл в Лейпцигском университете, который он выбрал потому, что там работал, как говорили, самьй лучший славист и один из основателей младограмматической школы - немецкий профессор Август Лескин (1840-1916), под эгидой которого существовал даже специальный институт болгарского языка, а Тихий в эти годы сосредоточенно занимался именно болгаристикой.

Между тем, из пражских педагогов Тихого выделялись - отец чешской литературной историографии Ярослав Влчек (1860-1930) и историк славянской литературы Ян Махал (1855-1939), с которыми он написал (под руководством Влчека и при оппонировании Махала) и 28 января 1913 года защитил докторскую диссертацию на тему «Баллады Франтишека Ладислава Челаковского» ${ }^{3}$, причём уже ранее (в 1911 г.) им была получена апробация в области чешского и немецкого языков, что позволяло ему преподавать в гимназиях.

Склонность к поэзии Тихий проявил в ранние годы: по его собственным словам, уже в младших классах гимназии он колебался в выборе между поэзией и музыкой (полгода писал стихи и полгода играл), печатал простые наивные стихи в детских журналах. Он учился в шестом классе (1903 г.), когда редактор литературного журнала «Besedy Času» Ян Гербен опубликовал стихотворение, которое написал Тихий, под псевдонимом Зденек Броман, придуманным приятелем автора Отакаром Типалом ${ }^{4}$, вскорости скоропостижно скончавшимся. Потом молодой поэт публиковался в журналах «Moderní život» Ярослава Га-

3 О Челаковском Ф. Тихий публиковал и первые специальные статьи: F. L. Čelakovský a slovanská vzájemnost, "Slovanský přehled" XV, 1912-1913, č. 1, s. 10-15 (подписано Z. Broman), и Příspěvky k studiu Slovanských národních písní od F. L. Čelakovského, (in:) Výročni zpráva městského reálného gymnasia v Berouně za r. 1914, Beroun 1914, s. 2-12; Йозеф Пата в кратком реферате о последнем названном исследовании подчеркнул, что здесь Тихий как последователь Яна Махала стремится доказать, что некоторые чешские песни из этого сборника, выдаваемые за народные, в действительности являются псевдофольклорными и принадлежат перу самого Челаковского и его сотрудника Йозефа Властимила Камарита (сравн. J. Páta, "Časopis pro moderní filologii" V, 1915-1916, s. 81-82).

4 Значительная часть публикационных материалов (особенно переводы и полемические заметки, а также рефераты о собственных работах) подписана псевдонимом Зденек Броман, что сохранено и при цитировании его текстов. 
шека, «Zvon» Матея Анастазия Шимачека, «Květy» и др. В 1908 году рукопись дебютной книги поэта (сборник вышел два года спустя под названием «Růžová a bílá knížka», Прага 1910) была удостоена стипендии фонда Юлия Зейера при Чешской академии наук и искусств ${ }^{5}$. Тихий использовал деньги для путешествия в Лужицу, где посетил серболужицкого народного поэта Якуба Барта Чишинского (1856-1909), и на Северное море.

В автобиографии Тихий пишет о своих первых переводах. Будучи учеником четвёртого класса гимназии, он купил у букиниста первый поэтический сборник Александра Блока «Стихи о Прекрасной Даме» и, как говорят, благодаря им, сам выучил русский язык. (Этот опыт свидетельствует о беспрецедентном лингвистическом таланте Тихого, которого мы можем назвать полиглотом - он переводил не только почти со всех славянских языков и немецкого, но и с французского, венгерского, английского и скандинавских языков, о чём свидетельствует его антология «Růženec útěchy» [Молитвенник отрады], Бероун 1929.) Позже он перевёл небольшую подборку символистических стихотворений Александра Блока и предложил их Адольфу Черному (о нём речь пойдёт далее) для его знаменитого славянского культурно-политического журнала «Slovanský přehled» (Славянский обзор). Черный, будучи сам поэтом и переводчиком, работу, которую сделал Тихий, хотя и похвалил, но не принял 6 , предложив, однако, амбициозному любителю поэзии делать переводы с болгарского, и таким образом на протяжении десяти лет Зденек Броман (так были чаще всего подписаны автором болгарские переводы) стал одним из самых прилежных исполнителей работы для «Славянского обзора». Но в 1912 году, когда после победы в войне с турками болгары не по-рыцарски напали на братьев-сербов, подающий надежды болгарист (в то время в области переводов произведений болгарской поэзии он не имел конкурентов) переориентировался на украинскую литературу и украинский язык.

5 Поэзией он занимался до конца Первой мировой войны - вышли следующие сборники стихов: 1914. Lyrická báseñ (Beroun 1914), Povídky a písně. Básně z let 1902-1911 (Beroun 1916) и Krvácející rány. Básně z let světové války (Beroun 1920).

6 Некоторые образцы из «своего Блока» Тихий напечатал в журнале «Květy»; это были вообще первые чешские переводы русского автора, несмотря на то, что из обширного материала переводчик выбрал только два стихотворения, сравн. A. Blok, *** ["Slyším zvony. Vesna na polích..."]. - S. M. Solovjevu ["U hrobů zapomenutých..."]. Přel. F. S. Tichý, "Květy" XXXII, 1910, 2. pol., s. 416. 
И когда после первой мировой войны Подкарпатская Русь отошла (мирный договор, подписанный в Сен-Жермен-ан-Лэ 10 сентября 1919 года) к недавно созданной Чехословацкой Республике, Тихий сосредоточил свой интерес на этом забытом славянском углу: в период с 1918 по 1938 год он занимался преимущественно научной работой, опубликовав огромное количество исследований и статей по литературной культуре Закарпатской Украины того времени, которые вышли, однако, отдельными публикациями («Pověsti z Podkarpatské Rusi» [Сказания Подкарпатской Руси], Кошице 1930; «Československé písně v "Moskevském zpěvníku" 》[Чехословацкие песни в «Московском песеннике»], Прага - Братислава 1931; «Anatolij Kralickij. Př́́spěvky ke studiu jeho života a díla» [Анатолий Кралицкий. Вклад в изучение его жизни и работы], Прага 1936; «Vývoj současného spisovného jazyka na Podkarpatské Rusi» [Развитие современного литературного языка Подкарпатской Руси], Прага 1938; посмертный украинский перевод эмоциональных мемуарных зарисовок «Ужгород 1923», Ужгород 1992) в различных отдельных изданиях ${ }^{7}$ и периодических сборниках («Carpatica, Науковий збірник Товариства «Просвіта» в Ужгороді»), а также журналах («Atheneum», «Slavia», «Bratislava», «Dunaj», «Naše doba», «Slovanský přehled», «Slovenské pohl'ady» и др. $)^{8}$.

Как Тихий отмечает далее в своей автобиографии, его работы публиковались и на украинском языке. Помимо многочисленных работ для ужгородских и прешовских русинских календарей и еженедельников, ряд его текстов содержится в ежедневнике «Русин», который был

7 Напр. Michail Lučkaj, (in:) Slovanský sborník F. Pastrnkovi, Praha 1923, s. 215-220; Písemnictví na Podkarpatské Rusi (Pohled z ptači perspektivy), (in:) Podkarpatská Rus. Obraz poměrů př́rodních, hospodářských, politických, církevních, jazykových a osvětových, Praha 1923, s. 151-160; První vlna západnictví v písemnictví podkarpatském, (in:) Sbornik prací věnovaných profesoru Janu Máchalovi k sedmdesátým narozeninám 1855-1925, Praha 1925, s. 267-276; Drobné př́spěvky ke studiu literární kultury Podkarpatské Rusi (Kdo byl Ivan Berežanin?), (in:) Z dějin východni Evropy a Slovanstva. Sbornik J. Bidlovi, Praha 1928, s. 372-375; Dobrovský a Podkarpatská Rus, (in:) Josef Dobrovský 1753-1829, Praha 1929, s. 332-343; Rusinská báseñ, věnovaná Andreji Sládkovičovi, (in:) Slovenská miscellanea. Sborník věnovaný univ. prof. Dr. Albertu Pražákovi k třicátému výročí jeho literární činnosti, Bratislava 1931, s. 91-93.

8 Для более подробной библиографии трудов Ф. Тихого сравн. Микола Мушинка, Франтішек Тіхий - 80 річний, "Дукля" XIV, 1966, № 3, с. 51-53; Orest Zilynskyj [ed.], Sto padesát let česko-ukrajinských literárních styků 1814-1964. Vědecko-bibliografický sbornik, Праха 1968, пассим [именной указатель 436, 447-448]; mk [= Milan Kudělka], Tichý František R., in: M. Kudělka - Z. Šimeček [et al.], Československé práce o jazyce, dějinách a kultuře slovanských národů od r. 1760. Biograficko-bibliografický slovník, Praha 1972, s. 471-473; es [= Eva Strohsová], František Tichý, (in:) L. Merhaut [ed.], Lexikon české literatury 4/I. S-T, Praha 2008, s. 915-917. 
им основан и которым он руководил 9 ; и даже перевёл на украинский язык стихи Яна Неруды «Matičce» (Матушке) для чешской антологии в библиотечке, изданной журналом «Русин». Как редактор и автор биографического предисловия, он приобрёл первое собрание произведений поэта Александра Духновича (укр. Олександр Васильович Духнович, 1803-1865) «Поезіи» [!] Александра Духновича (Ужгород 1922), а также из текстов величайшей украинской поэтессы Леси Украинки (укр. Леся Українка, 1871-1913) перевёл цикл «Cesta k moři» (укр. «Подорож до моря») и «драматическую феерию» «Lesní píseň» (укр. «Лісова пісня»; были опубликованы только отрывки, большая часть перевода осталась в рукописи $\left.{ }^{10}\right)$; далее Тихий подготовил подборку украинских стихотворений, посвящённых украинскими поэтами президенту Т. Г. Масарику «Т. G. Masarykovi ukrajinští básníci» (Прага 1936), и в то же время в качестве переводчика и литературного историка занимался поэзией Тараса Шевченко ${ }^{11}$.

Что касается профессиональной карьеры Ф. Тихого, то большую часть жизни он учительствовал в средних школах по всей Чехослова-

9 Ежедневник назывался «Русин. Чтоденна газета», выходил в Ужгороде, кроме понедельника, с 1.02. до 31.12.1923 г., был закрыт за недостатком средств.

10 Cравн. Lesja Ukrajinka, Cesta $k$ moři $I-I X$. Přel. Zdeněk Broman, "Slovanský přehled" XVI, 1913-1914, s. 97-102; Lesja Ukrajinka, Lesní píseñ. Úryvek. Přel. František Tichý. "Země" II, 1920-1921, s. 134-137; Геннадий Коновалов написал о технике переводов Ф. Тихого (по материалам его переводов из Леси Украинки) положительный отзыв: "Pro Bromana (Tichého) je charakteristická snaha po co nejbližší přesnosti překladu s originálem, a to přesnosti nejen doslovné, ale i umělecké. Danými prostředky českého jazyka převedl dosti dobře básnické hodnoty veršů naší velké básnířky. Překladatel velmi často nedodržuje počet a pořadí veršů v ukrajinském originále. Volné zpracování materiálu v mezích strofy mu dovoluje dosáhnout určité výraznosti. Je jisté, že v jeho překladech vytvořených téměř před půl stoletím [имея в виду 1963 г., т.е. больше чем один век тому назад - M. Ч.] je mоžno dnes nalézt celou řadu chyb a poklesků. Jsou tu jednotlivé nepřesnosti a méně zdařile přeložená místa. Ale přesto duch, obsah, systém obrazů i celkový kolorit originálu byl překladatelem zachován. V r[oce] 1919 přeložil František Tichý «Lesní píseň», ale tento překlad nespatřil v Československu světla ramp. Za dob buržoazní republiky díla L. Ukrajinky byla překládána jen řídce." Gennadij Konovalov, Lesja Ukrajinka u Čechů a Slováků, "Praha - Moskva" XIII (XXIII), 1963, č. 6 (listopad-prosinec), s. 367-369 (cit. 368).

11 Сразу трижды вышел отдельной книгой и один раз был напечатан в журнале перевод Тихого поэмы Сретик, известной в чешской среде под двойным названием Jan Hus (Kacír) (Praha 1918; 1919; 1921; журнальный вариант "Praha - Moskva" IV, 1939, č. 3, s. 79-83). Принципиальное значение для чешского восприятия украинской литературы имеет написанное по-украински исследование Тарас Шевченко в чеськіŭ та словачькій мовах, (in:) Тарас Шевченко, Повне видання творів Тараса Шевченка. T. XV, Варшава - Львів 1938, с. 357-385; чешскую выборку из этой работы Тихий опубликовал после войны в журнале "Praha-Moskva" II, 1947, с̌. 6, s. 145-147; с̌. 7, s. $188-189$. 
кии и, по возможности, путешествовал ${ }^{12}$. С 1911 года он преподавал в родном крае в гимназии города Бероун. В 1922 году стал управляющим евангелической гимназии в Прешове и там, впервые в истории словацкого школьного образования, ввёл в программу обучения украинский язык, но с нового 1923 года был назначен на работу в Ужгороде в канцелярию вице-губернатора с задачей основать русинский ежедневник, который он назвал «Русин» (см. выше), и руководить им. В 1924-1934 гг. он работал в качестве профессора гимназии в Братиславе. Кстати, уже перед Первой мировой войной (будучи вдохновлён своим учителем Я. Влчеком) Тихий занимался словакистикой и овладел словацкой речью и письмом (см. его книгу «Knížka о Slovensku» (Stati z let 1909-1919), Плзень 1919, и публикации в журналах «Slovenské pohl'ady» и «Sborník Matice slovenskej»).

В своей автобиографии Тихий упоминает и о различных неприятных обстоятельствах, из-за которых он в итоге не закрепился ни в одном из трёх чехословацких университетов, хотя и определённо хотел стать преподавателем высшего учебного заведения. В 1928 году он получил предложение от слависта и компаративиста Франка Вольмана

12 О посещении Лужицы и Лейпцига речь шла выше. Далее в своей автобиографии Тихий упоминает, что с 1920 года он регулярно посещал Львов и работал там в библиотеках и архивах. Как подтверждает его статья Jihoslovanští Rusíni. Črta informační, "Slovanský přehled" XX, 1928, s. 22-32, и запоздалое издание фрагмента записей собранных песен Po stopách Volodymyra Hnatjuka v Bačce a Srěmu, in: Vedecký sbornik Múzea ukrajinskej kultury vo Svidniku [= Науковий збірник музею української культури в Свиднику] 3, Prešov 1968, s. 112-126, в 1927 году он изучал жизнь н народное песенное творчество бывших русинских (украинских) переселенцев в Бачке и Среме (Срім) на территории Югославии. Весной 1932 года он участвовал в проходящих в Веймаре торжествах, посвящённых Гёте, путешествовал в Майсен по следам писателя и майсенского епископа Колды из Колдиц († между 1323-1327), входившего в круг Кунгуты Пршемысловны, и написал о результатах путешествия статью Frater Colda O. P., "Casopis Národního muzea" CXIII, 1939, s. 81-88. По дороге в Майсен он прошёл и по местам, связанным в Тюрингене с Яном Колларом (после войны он стал редактором избранных произведений Коллара: Vybrané spisy Jána Kollára, sv. 1-2, Praha 1952, 1956). Особое значение для него имел 1934 год, когда он принял участие в конгрессе национальных ПЕН-клубов, проходившем в Дубровнике; по этому случаю, он снова отправился к русинским колонистам в Югославию. Дальнейший заграничный путь Ф. Тихого в каникулярное время 1937 года отмечен его пребыванием в Варшаве, Вильно и Черновцах, где он привлёк к себе внимание своим интересом к белорусской культуре. Последние предвоенные каникулы 1938 года Тихий провёл в Амстердаме и Наардене в поиске мест, связанных с Яном Амосом Коменским, творчеством которого сосредоточенно занимался в военные годы: на конкурс клуба современных издателей Kmen он представил свою обширную монографию о Коменском (1942, издана не была), перевёл его Slovo k Evropanům, которое было издано в конце войны, а после освобождения «варварски брошено в ступу», и подготовил к изданию выборку его произведений в нескольких томах, часть из которых вышла даже несколько раз. 
(1888-1969) написать работу для получения звания доцента по специальности история славянских литератур и написал по этому поводу обширную работу «Obrozenská doba na Podkarpatské Rusi» (Время возрождения Подкарпатской Руси), но не предоставил её в связи с тем, что в то время в трёх наших университетах кандидатов на защиту по этой теме было четверо. Новую попытку он предпринял в 1931 году, когда опять же работавший в Братиславе историк Йозеф Гануш (1862-1941) предложил, чтобы Тихий с его работой «Československé písně v "Moskevském zpěvníku" 》 (Чехословацкие песни в «Московском песеннике», Прага - Братислава 1931) претендовал на звание доцента истории чешской литературы. Кроме того, Тихий подготовил подробное исследование «Dějiny české lyriky v době nejstarší» (История чешской лирики старейшего времени), но работа осталась в рукописи, а вопрос доцентуры был снят по причинам ненаучныл.

В 1934 году Тихий переехал в Прагу и преподавал в гимназии Йирасека на улице Ресслова до 1 сентября 1941 года, когда был преждевременно отправлен оккупантами на пенсию. Он предпринял третью попытку стать доцентом: в 1934 году его побудил к тому палеославист и византолог Милош Вейнгарт (1890-1939), который хотел, чтобы Тихий получил звание доцента в Карловом университете по теме украинский язык и литература. На основании уже изданной работы «Vývoj spisovného jazyka na Podkarpatské Rusi» (Развитие литературного языка в Подкарпатской Руси, Прага 1938) Тихий подал заявление о защите, но вскоре отозвал его, ибо профессор Вейнгарт в январе 1939 года умер.

Четвёртая, и последняя, попытка стать доцентом закончилась неудачей. В феврале 1939 года он подал заявку на защиту звания доцента по теме история чешской литературы в соотношении с гимнологией на евангелическом факультете Яна Гуса в Праге, на котором Тихий был записан как постоянный слушатель. Предложенная им работа была принята, Тихий даже был приглашён на 21 ноября 1939 года к сдаче защитительного коллоквиума, но 17 ноября того же года чешские высшие учебные заведения были насильственным путём закрыты оккупантами, и это временное положение действовало вплоть до освобождения.

В период 1940-1945 гг., когда официальная научная жизнь во всём Протекторате Чехия и Моравия была сведена до минимума, Тихий сосредоточился на исследовании деятельности Коллара (кроме подготовки к изданию поэтических произведений Тихий хотел издать и корреспонденцию Коллара, но до реализации проекта дело не дошло, и это неутешительное положение сохраняется и сегодня) и стародавней чеш- 
ской литературы. Это печальное время он описал более подробно в начале 50-х годов 20-го века в своей автобиографии «Životopis» [I.]. Кроме прочего, он пишет, что прежде чем он был отправлен на преждевременную пенсию, в гимназии Йирасека преподавал наряду с чешским языком и немецкий. По мере своих возможностей он старался бороться с оккупантами - напр. тем, что перевёл революционную песню «Ein feste Burg» Лютера, и известный поэт Йозеф Гора (между прочим, тоже переводчик белорусской поэзии), тогда редактор газеты «České slovo», пытался этот текст обнародовать, но безрезультатно, в связи с цензурой. После дальнейших безуспешных попыток стихотворение как новогоднее послание нелегально напечатал переплётчик Людвик Брадач.

В целом логично, что Тихий, будучи германистом, не отказался от предложения своего университетского профессора Йозефа Янко (1869-1947), председателя «Общества по сотрудничеству с немцами» и осенью 1939 года вступил в это германофильское общество: Я $n p u$ нял это предложение, потому что в то время собственной политической неграмотности предполагал, ито речь идёт об обществе неполитическом. Моё решение было упрощено тем, ито как раз в то время СССР подписал с Германией пакт о ненападении. В деятельности общества я участия не принял, а оккупанть в нём не нуждались и вели себя по отношению $к$ нему пассивно ${ }^{13}$. Й. Янко коллаборационистом не был и в качестве долголетнего главного редактора (1923-1947) выходящего даже в военное время профессионального периодического журнала «С̆asopis pro moderní filologii» давал Тихому для рецензий профессиональные книги неполитического характера ${ }^{14}$.

По окончании Второй мировой войны требовалось при написании автобиографии высказаться и о своём мировоззрении. Тихий имел левые взгляды, публиковался в левой печати и уже с 1925 года был членом «Общества культурно-экономического сближения с новой Россией», которое издавало русско-чешский журнал «Новая Россия / Nové Rusko». Во время войны он регулярно встречался в кафе «Тумовка»

13 František Tichý: Životopis [I.], s. 1, фонд Tuхий (см. прим. 3). - Оригинал: "Uposlechl jsem této výzvy, poněvadž jsem se v své tehdejší politické negramotnosti domníval, že jde o spolek nepolitický. Rozhodnutí mi usnadnil fakt, že právě v té době uzavřel SSSR s Německem pakt o neútočení. Činnosti Spolku jsem se neúčastnil, ostatně okupanti si činnosti spolku nepřáli a chovali se k němu pasivně".

14 Напр. русскую грамматику немецкого языка (Л. Р. Зиндер - Т. В. СтроеваСокольская, Научная грамматика немецкого языка, Ленинград 1938) или монографию о Р. М. Рильке (Е. С. Mason, Lebenshaltung und Symbolik bei Rainer Maria Rilke, Weimar 1939). 
со своим давним приятелем Антонином Боучеком, публицистом и бывшим редактором коммунистической газеты «Rudé právo», и благодаря нему познакомился с основами марксистско-ленинского учения, беря у него необходимую литературу, а главное, тенденциозно прославленную биографию Сталина «Staline. Un monde nouveau vu à travers un homme» (1935), написанную Анри Барбюсом. Эта книга вдохновила его (подобно ряду левых интеллектуалов того времени, и не только в Чехословакии) настолько, что он начал учить грузинский язык и изучать произведения Сталина. Ещё во время войны он написал для молодёжи краткую биографию Сталина, и её летом 1945 года приняло к изданию издательство «Орбис», но до печати дело не дошло.

После освобождения Чехословакии в мае 1945 года Тихий вступил в Коммунистическую партию Чехословакии и подал заявление в министерство образования с просьбой, чтобы ему было разрешено преподавать чешский язык в университете Киева, но просьба была отклонена. Тогда он отправился в Судетскую область и начал работу во вновь открывшейся гимназии в г. Марианске Лазне, параллельно продолжая преподавать в гимназии Праги-Михле. В 1947 году он уехал в словацкий Сваты Юр (Svätý Jur), где получил должность директора гимназии; заезжал и в Братиславу, где на филологическом факультете читал лекции чешского языка. В 1949 году он был отправлен на пенсию и вернулся в Прагу. В научном плане впоследствии он был связан главным образом с Прешовом: принял участие в двух общегосударственных украинистских конференциях (1956 и 1964), а в октябре 1956 года прочитал на философском факультете прешовского университета цикл лекций об украинской литературе ${ }^{15}$.

Ещё об одной интересной автобиографической детали времён сталинизма (после коммунистического переворота в феврале 1948 года) автор в своей автобиографии умолчал. Несмотря на свои левые взгляды и членство в Коммунистической партии Чехословакии, в начале 50-х годов он пережил опыт остракизма со стороны тоталитарного режима, который был утверждён по всей Чехословакии под прямым надзором Советского Союза, так же, как и на всех остальных советских сателлитных территориях - с недобрыми результатами новых политических отношений. Свидетельство об этих горьких для Тихого моментах (принудительное выселение из Праги, в которую он мог вернуться только через несколько лет) прозвучало в некрологе младшего

15 Cм. František Tichý: Životopis [II.], s. 2, фонд Тихий (см. прим. 3). 
коллеги учёного и лично близкого ему сотрудника Микулаша Мушинки $\left({ }^{*} 1936\right)$, известного словацкого украиниста, связанного с Прешовом и ставшего после 1968 года жертвой репрессий того времени (в период так называемой «нормализации» 1970-1989 годов он вынужден был быть пастухом коров и истопником). В связи с тем, что этот текст не является общедоступным, позволю себе процитировать этот отрывок полностью:

Здавалось би, що після другої світової війни перед Фр. Тіхим відкриються широкі двері в науку, але так не сталося. Його 20-річна діяльність на ділянці культурного і національного відродження Закарпаття ніяк не вміщалася в офіційні рамки, не співпадала з авторитативними твердженнями про те, що ніби чеська інтелігенція (буржуазія) намагалась денаціоналізувати закарпатське населення, штучно утримуючи його в неграмотності і культурній та економічній відсталості. Фр. Тіхому після визволення довелось прожити не одну гірку хвилину. На початку 50 -х років його з дружиною вивезено адміністративним порядком з Праги в Бероун. (Навіщо, мавляв, пенсисту квартира в Празі? Вистачить йому невеличка кімнатка на периферії. Питанням, куди він діне свою величезну бібліотеку, ніхто не цікавився.) Інший на його місці оганявся б активною діяльністю в "Společnosti pro sblížení s novým Ruskem", натхненними статтями про Радянський Союз з 20-30-х років, а врештірешт і партквитком давньої дати, але Фр. Тіхий був не з тих, він ніколи й ні перед ким не говорив про свої попередні заслуги.

Та і в тих найгірших умовах Фр. Тіхий не перестав науково працювати: продовжував писати монографію про Коменського, в чехословацькій і закордонній пресі він опублікував ряд літературознавчих та історичних праць, підготував до друку антологію старої закарпатоукраїнської літератури (ії рукопис знаходиться в Музеї української культури у Свиднику), брав участь в ряд наукових конференцій, в т. ч. і пряшівських тощо ${ }^{16}$.

Последние годы жизни Ф. Тихого проходили в одиночестве, ибо в 1966 году он потерял свою жену. Вдовец регулярно посещал её могилу у местечка Железна недалеко от Хинявы. В конце концов последняя из этих поездок символично - недалеко от места последнего упокоения любимой супруги - закончила его богатую жизнь: он был найден мёртвым около родного посёлка уже через несколько дней после кончины, как об этом было написано 6 апреля 1968 года в рубрике «Из чёрной хроники» ежедневной газеты «Rudé právo»: Около посёлка Хинява в районе Бероуна был найден мёртвый мужчина, который

16 Микола Мушинка, Невтомний дослідник закарпатоукраїнської культури Франmiшек Тіхий, ор. сіt. (прим. 1), с. 344. 
позже был опознан как доктор Франтишек Тихий из Праги-2, который приехал посетить могилу своей жень в посёлке Железна. По дороге с кладбища он сошёл с пешеходной дороги в поле, где был обнаружен мёртвым. Не было найдено никаких признаков насильственной смерти; вскрытие должно показать, идёт ли речь об инсульте 17 . Дата смерти была дополнительно установлена на 4 апреля 1968 года. Кремирование и похороны прошли тихо, без речей и участия близких друзей и коллег покойного. Кроме уникального некролога Мушинки, не вышел ни на украинском, ни на словацком, ни на чешском языке ни один другой некролог, который бы отдал дань памяти Тихому и оценил его богатую и разнообразную деятельность в области германистики, славистических дисциплин, истории чешской литературы и художественного перевода, несмотря на то, что, по словам Мушинки, нескольким братиславским и киевским редакциям периодических изданий были надіслані не лише матеріали про життя $i$ творчість Фр. Тіхого, але й готові статті. Невже ж багатогранна діяльність Ф. Тіхого справді упаде в забутmя? 18

\section{II. Белорусоведческая деятельность Ф. Р. Тихого}

Необходимо отметить, что деятельность Тихого в области белорусистики отмечена в нескольких контактологических работах на тему взаимоотношений и восприятия чешской и белорусской литератур (которые будут отмечены в тексте далее), но ни одна из них не рассматривает комплексный вклад чешского учёного и переводчика так, как это должно рассматриваться в полномасштабной монографии, и чешский пропагандист белорусской культуры и литературы, к сожалению, не отмечен даже в обширной и представительной энциклопедии «Беларуская энцыклапедыя у 18 тамах» ${ }^{19}$.

Во многих отношениях на Тихого повлиял как пример его советчик и консультант Адольф Черный (1864-1952), известный славист, пере-

17 Z Černé kroniky, "Rudé právo" XLVIII-XLIX, 1968, č. 96, s. 5, 4. 4. - Оригинал: "U obce Chyňava, okres Beroun, byl nalezen mrtvý muž, ve kterém byl později zjištěn dr. František Tichý z Prahy 2, který byl navštívit hrob své ženy v obci Železná. Cestou ze hřbitova sešel z pěšiny do pole, kde byl nalezen mrtev. Nebyly zjištěny žádné známky násilí a soudní pitva má prokázat, zda se jednalo o mrtvici".

18 Микола Мушинка, Невтомний дослідник закарпатоукраӥнськоӥ культури Франmiшек Тіхий, ор. cit. (прим. 1), с. 344.

19 Сравн. Беларуская энцыклапедыя у 18 тамах. Том I-XVIII, Мінск 1996-2004. 
водчик, долголетний редактор выдающегося культурно-политического журнала «Slovanský přehled» (далее «Славянский обзор»; в годы 18981914, 1925-1930), поэт (использовал псевдоним Ян Рокита) и, кроме того, деятельный первопроходец белорусистики в Чехии ${ }^{20}$. Тихий познакомился с Черным ещё будучи студентом и посвятил ему стихотворение «Sen» (Мечта), напечатанное в беллетристическом приложении студенческого журнала «Studentský věstník» (№ 4, 4.12.1905). В наследии Черного сохранился печатный текст со следующим автографом: Прославленному поэту Я. Роките позволил себе написать здесь это как неяркое доказательство своей признательности и искренней преданности Зденек Броман 21.

А почти через год - в сентябре 1906 гола - Черный напечатал прямо на первых страницах 1-го номера 9-го годового издания «Славянского обзора» переводы Бромана из двух болгарских поэтов - Кирилла Христова (1875-1944) и Пейо К. Яворова (1878-1914). Даже в области художественного перевода Тихий-Броман относил себя к приверженцам поэтической техники своего учителя, опирающегося на теоретические принципы школы лумировцев ${ }^{22}$, прогрессивных и актуальных преимущественно в 70-80 годах 19-го века и устаревающих в начале 20-го столетия.

20 К белоруссистическим интересам Ф. Тихого см. А. Мажэйка, Беларуская літаратура ў чэшскіх перакладах, (in:) Н. С. Перкін [ed.], Садружнасць літаратур, Мінск 1968, с. 105-109 (полное исследование 103-134); М. І. Чмарава, Шляхі ўзаемнага пазнання: беларуская літаратура ў Чехаславакіi (1920-1945). Манаграфія, Магілеў 2004, c. 79-86; M. Černý, Adolf Černý jako první český překladatel novodobé běloruské literatury, "Slavia" LXXXII, 2013, č. 1-2, s. 69-111; М. Черны, Адоль $\varnothing$ Черный и белорусская литература, "Białorutenistyka Białostocka" 2014, t. 6, s. 51-68.

21 Фонд Adolf Černý, IIb1 - F. Tichý (korespondence), karton 33, Институт Масарика и Архив Академии наук Чешской республики (Masarykův ústav a Archiv Akademie věd České republiky), Прага (далее фонд Черный). - Оригинал: "Slovutnému básníku J. Rokytovi dovolil si připsati toto jako nepatrný důkaz svojí vděčnosti a důvěřivé oddanosti Zdeněk Broman".

22 У лумировцев преобладало стремление переводить в целом правильно и в исходном размере оригинала, то есть в процессе перевода понять прозодическую и содержательную основу иноязычного оригинала, даже ценой определённого насилия над чешским языком. - Черный внимательно следил за переводческой работой Тихого и, например, в письме от 23.08.1918 высказал ему следующую похвалу: "Srdečné díky za Váš překlad Ševčenkova «Jana Husa» - a zejména za laskavé věnování, které mi jest důkazem, že rád vzpomínáte na mé podněty ke studiu slovanských jazykův a literatur. Já zase s potěšením vidím, že mé podněty padly na půdu úrodnou. Překlady z Botjova [чешский поэтический сборник Básně болгарского поэта Христо Ботева (1848-1876) вышел в Праге в переводе Бромана в 1913 году - M. Ч.] a Ševčenka - kromě řady překladů ve Sl[ovanském] přehl[edu] - jsou toho důkazem". Письма Черного Тихому находятся в уже упомянутом фонде Тихий (см. прим. 3). 
Для Тихого Черный был авторитетом в области белорусистики. Две цитаты из его портретной работы «Dílo a osobnost Adolfa Černého» (Деятельность и личность Адольфа Черного) ${ }^{23}$, характеризующие, кроме прочего, неугасаемый интерес, проявленный Черным по отношении к забытым славянским народам и их культуре, показывают, что ценит ученик в своём учителе в отношении к белорусам: Особое внимание Черный уделял белорусам, как и вообще искал для своей работь наименее известнье области. О народном белорусском движении он писал в изданиях: «С̆аs» 1906 и 1907 г2., «Zlatá Praha»1907 г., а главное, в статье «Белорусские народные и литературные стремления в 1909-10 г2.» («Slovanský přehled»XIII, 1911, 217 и дp.). В этой статье Черный также привёл первье переводы из белорусской поэзии ${ }^{24}$. И через несколько страниц далее написал: Свой взгляд на славянский вопрос Черны изложил спокойно и ясно в знаменитой статье «О славянской взаимности в современности», напечатанной в журнале "Naše doba"》 XIII, 1906, в которой он ставит критерием правильного понимания славянского вопроса отношение к России. Романтическое понимание славянского вопроса представляется как культ власти и силь без моральных терзаний. Исходя из этого глубоко морального довода, «Slovanský přehled» становится на сторону угнетённых украинцев и белорусов ${ }^{25}$.

В подобном же духе написаны письма Тихого к Черному. Напр., в письме от 5.02.1925 г. Тихий воодушевлённо реагирует на предложение Черного снова стать сотрудником обновлённого «Славянского обзора»: Я буду прилежно работать над всеми Вашими заданиями, u, в первую очередь, в области болгарской литературы, с которой я начинал у Вас, и литературь украинской. Если у Вас нет никого

23 František Tichý, Dílo a osobnost Adolfa Černého, in: A. Frinta - F. Tichý [edd.], Slovanský přehled 1914-1924. Sbornik statí, dopisü a zpráv ze života slovanského. K šedesátým narozeninám Adolfa Cerného, Praha 1925, s. 31-49.

24 Там же, с. 38. - Оригинал: "Zvláštní pozornost věnoval Černý Bělorusům, jakož vůbec vyhledával si pro práci oblasti nejméně známé. O národním hnutí běloruském psal v Čase 1906 a 1907, ve Zlaté Praze 1907 a hlavně ve stati «Běloruské snahy národní a literární v letech 1909-10» (Slov[anský] př[ehled] XIII, 1911, 217 a další). V této stati přinesl též prvé české př̀klady z běloruské poezie".

25 Там же, с. 44. - Оригинал: "Svůj názor na slovanskou otázku vyložil Černý vědecky klidně a jasně v znamenité stati «O slovanské vzájemnosti v době přítomné» v Naší době XIII, 1906. Zde stanoví jako kritérium správného pojímání slovanské otázky poměr k Rusku. Romantické pojetí slovanské otázky je podle toho kult moci a hmotné síly Ruska bez mravních skrupulí. Z tohoto hluboce mravního důvodu staví se «Slovanský přehled» na stranu utlačovaných Ukrajinců a Bělorusư". 
более подходящего, могу взять также на себя заботу о литературе белорусской ${ }^{26}$. В письме от 18.09.1925 г. он с удовольствием принимает задание написать о поэме Якуба Коласа «Сымон Музыка», к чему его Черный сам и призвал: Об эпосе Коласа буду рад дать отзыь, тем более, что белорусскими делами я занимаюсь уже долго и систематически. Книгу, однако, найду себе сам, а Вашу с благодарностью возвращаю ${ }^{27}$. Эта цитата иллюстрирует взаимное доверие коллег и свидетельствует о страсти Тихого к славянской поэзии - подобным образом переводчик находил для себя также болгарские, украинские и другие сборники, тратя на них немалые деньги.

Однако Тихий смог выполнить не все обещания. Так, например, в письме от 6.09.1929 к Черному он обещал написать реферат о книге Е. Ф. Карского «Geschichte der weissrussischen Volksdichtung und Literatur» (Berlin 1926), но, в конечном итоге, никакая публикация Тихого о немецкой монографии всемирно известного белорусиста не вышла, ибо, очевидно, не была написана вообще из-за перегруженности в работе.

В связи с тем, что белорусские оригиналы переведённых Тихим текстов недоступны в Праге, в настоящее время у автора нет возможности точно оценить в этой работе общий вклад Франтишека Тихого в чешскую белорусистику, и даже гарантированно верно определить все названия переведённых стихотворений, и, тем не менее, я попробую представить общий список его опубликованных и сохранённых в пражском наследии переводов, а также позволю себе сделать несколько попыток критического анализа его переводческой работы.

Об открытии для себя белорусов, их языка и словесности Тихий оставил в своём наследии свидетельство в воспоминании, названном «Mé běloruské vzpomínky» («Мои белорусские воспоминания»; этот текст до сих пор не был опубликован, поэтому я его привожу полностью в конце работы в приложении вместе с русским переводом) $)^{28}$.

26 Все цитируемые письма Тихого к Черному находятся в уже упомянутом фонде Черный (см. прим. 22). - Оригинал: "Budu pilně pracovati na všem, co mi přidělíte, tedy ovšem v prvé řadě v oboru literatury bulharské, jíž jsem u Vás začínal, i v oboru literatury ukrajinské. Není-li nikoho povolanějšího, mohu si též vzíti na starost literaturu běloruskou".

27 Там же. - Оригинал: "O Kolasově epose rád budu referovati, tím raději, že se běloruskými věcmi zabývám už delší čas soustavněji. Opatřím si však knihu svou, a proto s díkem současně Váš výtisk vracím".

28 F. Tichý: Mé běloruské vzpomínky [далее Мои белорусские воспоминания], недатированная машинопись, 2 стр., очевидно, после 1955 г., фонд Тихий (см. прим. 3). 
Интерес к белорусскому языку в Тихом пробудил пражский студент Микола ${ }^{29}$ Шиманка (1901-1986) - уже в 1923 году Тихий купил в Ужгороде первые белорусские книжки, а скорее, брошюрки с произведениями Леопольда Ивановича Родзевича (1895-1938) «Беларусь. Вершы» (Вільня 1922) и «Досвіткі. Драматычныя сцэнкі» (Вільня 1922). Позже, когда Тихий работал преподавателем в средней школе, он не мог лично познакомиться с Янкой Купалой во время посещений последнего Праги в 1925 и 1927 годах ${ }^{30}$, хотя и очень хотел этой встречи (возможно, на эту тему он в 1927 году вёл переписку с пражскими белорусами). Белорусский поэт послал ему (очевидно, будучи кем-то предупреждён о личности Тихого) два тома своих сочинений «Збор твораў» со следующим посвящением: Высокопаважному праф[есару] Ціхаму на добры успамін з пашанай Янка Купала. Менск 1.XII.192\%. С этого момента Тихий начал переводить поэзию Купалы.

Часть этих переводов вышла в различных периодических изданиях и в сборнике «Bělorus a Bělorusové» («Беларусь и белорусы», Прага 1930), подготовленном Миколой Ильяшевичем (1903 - после 1945 г. $\left.{ }^{31}\right)$, который сыграл роль первопроходца в области художественного перевода с белорусского языка, будучи редактором (и частично автором) первого популярного пособия о белорусах со старательно подготовленной антологией в приложении.

Самым старым чешским переводом из Купалы является фрагмент стихотворения «Ужо днее», напечатанный Адольфом Черным в январе 1909 года, но более ясное представление о поэзии Купалы чешский читатель получил из небольшой подборки из сборника «Спадчына» (1922), представленной читателю опять же Адольфом Черным (под псевдонимом Йиржи Рубин) в 1926 году ${ }^{32}$. Тихий имел материал, на который мог опереться и целенаправленно выбирал ещё не

29 Ф. Тихий (вероятно, под влиянием украинского языка) в рукописи приводит непривычную для белорусского языка форму «Мыкола»; о Шиманке вновь рассказывает М. І. Чмарава, Шляхі ўзаемнага пазнання, ор. cit. (прим. 21), с. 102-106.

30 Пребывание Янки Купалы в межвоенное время в одной из частей бывшей Чехословакии - в Словакии - детально и исчерпывающим образом задокументировал и оценил белорусский литературовед Микола Трус; посещением Купалой Чехии он, однако, не занимался; сравн. Мікола Трус, Янка Купала ў Славакіi, Мінск 2012.

31 После освобождения Чехословакии в 1945 году был задержан советскими органами, и о его дальнейшей судьбе ничего неизвестно, сравн. Daniela Kolenovská, Běloruská emigrace v Československu (1918-1938), "Soudobé dějiny" XIV, 2007, č. 1, s. 97 (полное исследование 78-105, 243-244).

32 Более подробно см. Марцел Черны, Адольф Черный и белорусская литература, op. cit. (прим. 21), с. 59-66. 
переведённые стихи, за исключением «белорусского гимна» «А хто там ідзе?»33.

Первым в этом ряду Тихий обнародовал отрывок (1 часть) поэмы Купалы «Z jubilejních nálad» (3 угодкавых настрояў), написанную в 1927 году к 10-й годовщине Октябрьской революции (выделено - M.Ч.):

3 угодкавьх настрояу

1

Як пабег тады той

Вокліч ды па хатах:

«Гэй, на сход сыходзься!

Дзень ідзе расплаты.

Выпала часіна

Падвясці злічэнне

Крыўды векавечнай,

Вечнага цярпення.

Помстай за знявагу

Ды за катаванне

Дзякаваць удзячна

3 вечара да рання.

Кузні і палеткі

Чысціць днём і ночай

Ад крыві мужыцкай, Ад крыві рабочай.

Хай дымяць пажары

Тут і там крывава,

Каб было скрозь відна,

Як ідзе расправа...»
Z jubilejních nálad

1.

Jak náhle vznesl se

ten výkřik nad chaty...

"Tak, vzhůru na tábor!

Den vzchází odplaty.

Nadešla hodina,

kdy zúčtujeme již

ty křivdy odvěké

a utrpení tíž.

$\mathrm{Z}$ rána do večera

chcem za těch potup řad

a za ubíjení

svou pomstou děkovat.

Budeme čistiti

pole i dílny své

od krve sedláků,

od krve dělnické.

Necht' planou požáry,

krvavé záplavy,

by bylo viděti,

až soud se dostaví..."

33 Перевод Тихого (Kdo to kráči sem? "Národní osvobození" XII, 1935, č. 192, 18. 8., př́l. Hodina, č. 27, s. 11) я сравнил с остальными чешскими переводами в своей статье (сравн. Адоль Черный и белорусская литература, ор. cit. [прим. 21], с. 62-64); стоит посмотреть на творческую мастерскую Тихого через призму его уже упомянутого труда Мои белорусские воспоминания (см. прим. 29), стр. 2: «Во время своей переводческой работы я начинаю с того, что перечитываю вслух выбранное стихотворение так долго, что начинает вырисовываться поэтическая копия на моём родном языке. Предполагаю, что благодаря этому способу мне удалось ухватить ритмику оригинала при переводе классического стихотворения Купалы $A$ xто там iдзе, что не удалось ни моему предшественнику Адольфу Черному, ни последователю Камилу Беднаржу». Музыкальность, бесспорно, принадлежит к одному из преимуществ переводов Тихого, а его художественная раздвоенность в выборе между музыкой и поэзией известна из его собственного признания в автобиографии. 
I ўздрыгнуй сатрапа, Задрыжэў багаты,

Як пабег тады той

Вокліч ды па хатах ${ }^{34}$.
Zatřás se satrapa, zachvěl se bohatý, jak náhle vznesl se ten výkřik nad chaty ${ }^{35}$

Можно согласиться с А. Мажейко, что Тихий здесь следует примеру А. Черного и заботится о филологической точности и верности отображения духа основного текста, старается ухватить и передать в максималистской мере стиль оригинала: Змест $i$ інтаначы верша перададзень з максімальнай дакладнасцю, перакладчык імкнуўся не адыходзіџь ад арыгінала нават у галіне лексікі і фразеалогіi (... $)^{36}$.

С точки зрения лексики, интересна конкретизация общего слова «сход» в переводном варианте слова «tábor» (лагерь), часто употребляемом в чешской среде (в корреляции с гуситской традицией) в значении «tábor lidu» (лагерь людей), «masové shromáždění pod širým nebem» (народное собрание под открытым небом), «manifestace» (манифестация).

В пражском наследии Тихого сохранилась машинопись варианта этого перевода с более выраженным бойцовским настроением с особым обострением в 3 и 5 строфе, но напечатать это вряд ли разрешила бы цензура (упомянутые выражения выделены жирным шрифтом):

Od rána do noci

budem za podlý řád

a za to vraždění

se pomstou děkovat.
Necht' vzplanou požáry,

krvavé záplavy, abychom viděli, až soud se dostaví...

Вместо глагола «хотеть» использовано «будем»; вместо «за многие позоры и унижения» [za těch potup řad] переводчик в целом отклоняется от исходной семантики и обвиняет всё государственное устройство («подлый закон» [podlý řád]; Купала под этим, однако, подразумевал царскую Россию), умеренное «убивание» [ubíjení] заменено на «убийство» [vraždění], пожары должны «воспылать» [vzplát] (опять усилена

34 Янка Купала, Збор твораў у шасиі тамах. Вершы $і$ паэмы 1918-1932, Мінск 1962, 3 угодкавьх настрояў [1], т. 5, с. 214-215.

35 Janka Kupala, Z jubilejních nálad [1.]. Přel. F. Tichý. "Národní osvobození" V, 1928, č. 299, 28. 10., př́l. Hodina, č. 44, s. 2; перепечатано (in:) M. Iljaševič, Bělorus a Bělorusové. Český čtenář 21, sv. 6-7, Praha 1930, s. 101-102.

36 А. Мажэйка, Беларуская літаратура ў чэшскіх перакладах, ор. cit. (прим. 21), c. 111 . 
аппелятивность), безличное «чтобы было видно» [by bylo viděti] заменено на конкретизированное «чтобы мы видели» [abychom viděli] ${ }^{37}$.

Наряду с вводной песней Тихий перевёл ещё предпоследнюю (5) часть, заманивающую своей музыкальностью и народным тоном, напоминающим военные и рекрутские песни (выделено - М. Ч.):

5

Зацымбалілі цымбалы, Забубнелі бубны,

Як вярталіся з паходу,

3 бойкі вельмі труднай.

Сустрачалі маткі, сёстры

I зблізку, і здаля,

Адны плакалі ад шчасця,

Другія ад жалю.

Падлічалі, вылічалі,

Шмат не далічылі...

Ой, вяліку дань аддалі

Варожае сіле!

Ля гасцінцу, ля дарогі

Курганок віднее,

А на ім - штогод вяночак

3 беленькіх лілеяў.

Не забылі добры людзі

Ваяка за долю,

Што злажыў сваю галоўку,

Як травінку ў полі.

Не забылася дзяўчына

Курганка ля шляху:

Кожны год вянок прыносіць

И кладзе бяз жаху.

Зацымбалілі цымбалы,

Забубнелі бубны,

Як вярталіся з паходу,

3 бойкі вельмі труднай ${ }^{38}$.
5.

Cimbály se rozzvučely, bubny břeskně zněly,

když se $\mathbf{z}$ vojny velmi trudné domů navraceli.

Potkávali matky, sestry, zblízka nebo zdáli -

jedny zaplakaly štěstím, druhé hořem štkaly.

Počítali, sečítali, nevypočítali...

$\mathrm{O}$, té síle nepřátelské velikou daň dali.

Podle cesty při pěšině můžeš růvek zříti,

na něm každým rokem věnec z běloučkého kvítí.

Dobří lidé na vojáka nezapomínali, vždyt' on složil hlavičku svou jako travku v dáli.

Nezapomíná ni děva na ten růvek v pláni, rok co rok sem vínek klade v tichém přemítání.

Cimbály se rozzvučely, bubny břeskně zněly, když se $\mathbf{z}$ vojny velmi trudné domů navraceli ${ }^{39}$.

37 Janka Kupala, Z jubilejních nálad [1., 5.], недатированная машинопись (очевидно, 1934-1935 г., в качестве материала для радиопередачи - сравн. далее), s. 1, фонд Тихий (см. прим. 3).

38 Янка Купала, Збор твораў у шасиі тамах. Вершы $i$ паэмы 1918-1932, Мінск 1962, 3 угодкавых настрояў [5], т. 5, с. 218.

39 Janka Kupala, Z jubilejních nálad [5.]. Přel. F. Tichý, (in:) M. Iljaševič, Bělorus a Bělorusové, op. cit. (прим. 36), s. 102-103. 
Тихому здесь удалось подчеркнуть псевдофольклорную выразительность исходного текста (особенно заметны уменьшительно-ласкательные слова "курганок" - "růvek", "З беленькіх лілеяў" - "z běloučkého kvítí", "галоўку" - "hlavičku", "травінку" - "travku") и однотонный ритм, напоминающий удары цимбалов и бубна на траурном шествии. Единственное замечание может быть к уже необычному в современном чешском языке сочетанию "z vojny velmi trudné", в котором использование архаического адъектива "trudný" ( "smutný", "chmurný" , "obtížný") было обусловлено, очевидно, звучанием, сходным с нейтральным белорусским словом "трудны" (в значении "těžký", "obtížný").

Выбрав 1 и 5 части поэмы, переводчик создал диптих, наполненный внутренним напряжением противоречия призыва к деятельности и пацифизма: в то время как первая часть наполнена призывом к революции и борьбе за социальную справедливость и равенство во имя ликвидации богатых и деспотической власти («сатрапов»), другая часть звучит примирительно, и даже элегически (женщины плачут, девушки посещают могилы своих павших возлюбленных, возвратившиеся солдаты не могут досчитаться своих товарищей), буквально как memento, напоминающее о страданиях воинских жертв и в то же время незаменимости человеческой жизни.

В 30-е годы 20-го века Тихий напечатал ещё несколько переводов из Купалы: поэтическое кредо «Prý zpívám» (Вы кажаце...), лирическое стихотворение «Tu stojím, ruce kř́žem» (Злажыўшы руки...), уже опубликованный фрагмент «Jubilejní nálada» (3 угодкавых настрояў - 5. $)^{40}$ и одическая песнь родине «Mladá Bělorus» (Маладая Беларусь) из сборника «Шляхам жыцця» (1913). Посмотрим хотя бы на первую и две последние строфы последнего из перечисленных стихотворений (подчёркнуто - М. Ч.):

Маладая Беларусь

Вольны вецер напеў вольных песень табе, Бор зялёны ўзняў дружным гоманам, Сонца полымем вызвала к слаўнай сяўбе, Зоры веру ўлілі сілам зломаным.

$[\ldots]$
Mladá Bělorus

Van volný nazpíval ti volných písní směs, bor zelený své echo druží mile a slunce vyzývá svým plamem k setbě dnes a hvězdy víru vlily skleslé síle.

$[\ldots]$

40 Сравн. Prý zpívám. Přel. F. Tichý, "Čin” I, 1929-1930, č. 50, s. 1193, 9.10.1930; Prý zpívám... - Tu stojím, ruce křížem. - Jubilejní nálada [5.]. Přel. F. Tichý, "Země" XIV, 1933-1934, č. 2-3, s. 78-80, 31.1.1933; Prý zpívám. Přel. F. Tichý, "Národní osvobození" XII, 1935, č. 234, s. 1, 8. 10. 


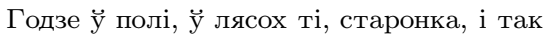
Сіратой начавала забытаю,

Годзе выпіў крыві з сэрца крыўды чарвяк, Косці вецер тачыў непакрытыя.

Падымайся з нізін, сакаліна сям'я, Над крыжамі бацькой, над нязгодамі, Занімай, Беларусь маладая мая, Свой пачэсны пасад між народамі! ${ }^{41}$
Už dosti po polích a lesích bloudila jsi jako dítě siré, opuštěné; už dosti krve ti zlá křivda vypila, a vítr honí kosti nepohřbené.

Nuž, plémè sokolí, z těch nížin $\mathrm{k}$ nebi výš, nad kříže předků tvých a nad vši svádu! Ó, Bělorusi má, ty mladá, zaplň již své čestné místo $\mathbf{v}$ národů všech řádu! ${ }^{42}$

Этот маленький пример показывает все достоинства и недостатки техники перевода Тихого: сохранён стихотворный размер, ритм и поэтическая образность, но стилистически перевод «похож» на образцы поэзии лумировцев последнего десятилетия 19-го века, т.е. поэзию по отношению к 30-м годам 20-го века уже значительно устаревшую - беглость и естественность стиха Купалы присутствует, но переводчик вынужден прибегнуть к поэтизмам, которые, по соображениям стихотворного размера, сокращают нейтральные слова («van» вместо «závan», «vanutí»; «plam» вместо «plamen»), а также к архаизмам («siré», «plémě», «nad vši svádu»), к изменённому порядку слов («volných písní směs», «bor zelený», «v národů všech řádu») или к использованию фонетически похожих слов, на чешском языке звучащих непривычно («Van volný», «volných písní», «bor (...) své echo druží mile», «hvězdy víru vlily»).

В неизданном наследии Тихого осталось ещё несколько переводов из Купалы: обширное (три машинописных страницы) стихотворение «Pod šibenicí» (Под виселицей; Перед виселицей), приветствие к 5 годовщине издания газеты «Наша Ніва», переименованное на «Nepohasnou...» (Не угаснут...; «Нашай Ніве» - «Не загаснуць зоркі ў небе») и образец природной лирики «Olšе» (Ольха; Вольха). О причинах, почему эти стихи не были опубликованы, мы можем только догадываться. Со стихотворением «Pod šibenicí» всё более чем понятно: его не пропустила бы цензура, напр. из-за следующих строк (14 - и финал), которые нужно воспринимать в первую очередь в контексте событий 1908 года, когда произведение было написано, но чехословацкой антисоветской общественностью они могли быть восприняты и трактованы как реакция на современные отношения:

41 Янка Купала, Збор твораў у шасиі тамах. Вершы $і$ паэмы 1911-1917, Мінск 1961, Маладая Беларусь, т. 3, с. 137-138.

42 Janka Kupala, Mladá Bělorus. Přel. F. Tichý, "Slovanská revue" I, 1934-1935, č. 5, leden 1935, s. 25. 
Перад вісельняй

Вы братняй кроўю ап'янелі,

Усіх звяроў сталі падлей, -

Вы разнікоў прайшлі на дзеле -

Ў разніцу гоніце людзей.

[...]

Яшчэ прыбавіце скананне -

Прадсмертны вашых рук абраз, -

Ня доўга ж ваша панаванне -

Загуба прыйдзе і на вас!

Загубу крыўдаю, слязамі

у магільны выкапалі ніз;

Людской расплаты ўжо над вамі

Тапор адточаны завіс.
Pod šibenicí

Vy krví bratrskou jste zpilí, všech zvířat podlejší vy jste, k řeznictví jste se obrátili, na jatky lidi honíte.

[...

Chystáte ještě umírání váš vlastní smrti předobraz... Již končí vaše panování a zhouba zachvátí i vás.

Hrob kopáte tak sami sobě svou křivdou, bližních slzami; odplata přijde v krátké době meč její visí nad vámi.

...Дзе ж кат?.. Гэй, шэльма, вешай лоўка!.. Kat zde? - Hej, šelmo, věš jen hbitě...

Не меў я волі, ні вугла...

Co volnost, nevím bezmála...

Намыль з канца ў канец вяройку,

Каб лепей шыю абняла!

Oprátku dobře namydlite, by lépe hrdlo objala.

ў паветры ногі затрасуцца,

Байца не стане аднаго,

Дый хоць званы й не адгукнуцца,

Не пахаваеце ўсяго!

V povětří nohy zatřepou se, nevydrží tu bázlivec,

a i když zvony neozvou se, ne, nepohřbíte všecko přec!

Не уммруць ніколі грозны клікі

На сонца захад і на ўсход:

Тут спіць ваяк, ваяк вялікі

За волю, долю і народ! ${ }^{43}$

Hlas hrůzný nikdy nedozní tu od východu až na západ:

Zde vojín, velký vojín spí tu, jenž za volnost a národ pad!

В стихотворении «Nepohasnou...» препятствием является тот факт, что оно написано по определённому случаю с излишним, по чешским представлениям, пафосом и потому, что переводчик в целом с задачей не справился и его вариант звучит несколько топорно, а стих выглядит банально (для иллюстрации цитирую три последних строфы; подчёркнуто $-M . Ч$.$) :$

«Нашай Ніве»

Беларускаю рукою

Светлай праўды сіла

Славу лепшую напіша

Бацькаўшчыне мілай.

Зацвіце яна, як сонца

Пасля непагоды,
Nepohasnou...

Běloruskou rukou bude světlé pravdy síla psáti lepší slávu vlasti, jež je nám tak milá.

Ona zazáŕí jak slunce, jak po bouřce bývá,

43 Янка Купала, Збор твораў у шасиі тамах, Вершы $i$ паэмы 1908-1910, Мінск 1961, т. 2, с. 60-61. 
$\ddot{y}$ роўнай волі, у роўным стане

Між усіх народаў.

Не загіне край забраны,

Покі жывы людзі, -

Не загаснуць зоркі $\ddot{\mathrm{y}}$ небе,

Покі неба будзе! ${ }^{44}$ в ровности а ве свободег bude $\mathrm{v}$ lidstvu živa.

Nezhyne kraj porobený, dokud lid v něm zbude.

Nepohasnou hvězdy v nebi, dokud nebe bude.

Недостатки перевода довольно очевидны. Выбор пары рифм «síla» - «milá» находится в соответствии с образцом («сіла»-«мілай»), но следующая пара не соответствует ему, неудовлетворительно звучание вспомогательного глагола быть/бывать и его форм («bývá» - [bude] «živa», «zbude»-«bude»). Кроме того, Тихий, в противоречие с оригиналом, рифмы «исправил» (у Купалы находим, напр., «непагоды»«народаў», «людзі»-«будзе»), и этим упорядочением и уточнением исказил игривое несовершенство исходного текста (здесь я имею в виду определённую вольность цитированных рифм Купалы: в рифмованных парах отличаются гласные -ы - -аў и -і - -е, т.е. совпадение не абсолютно, оно намеренно нарушено). Кроме того, Тихий использовал неуклюжую грамматическую пару «zbude» - «bude».

В стихотворении «Olšе», датированном 14 августа 1906, достоин внимания тот факт, что вместе с переводом Тихого и белорусским текстом в архиве хранится и рукописный вариант украинского перевода, сделанного Микитой Шаповалом в 1909 году. Сначала я предполагал, что переводчик поступил нестандартно и переводил не оригинал, а украинский текст, в связи с чем считал перевод несовершенным и не готовым к печати. Однако сравнение оригинала с двумя иноязычными переводами недвусмысленно свидетельствует о том, что Тихий переводил прямо с белорусского языка (выделено - М. Ч.):

Biльxa

Шумить вільха і тужить

Над річкою сумною,

І сушать іï ноги

Бур'ян із кропивою.

Над нею сине небо

Негодою лиш сіє -

То студять ї̈ зими,

То палять суховії.
Olše

Smuteční olše šumí nad říčkou pod skalami, obrostlá nad kořeny bodláky, kopřivami.

Nad ní se modrá nebe a nepohodu seje: tu rozmrazí ji zimy a tu zas léto hřeje.
Вольха

Шуміць маркотна вольха Над рэчкаю бурлівай, Аброслая на доле Бадылямі, крапівай.

Над ёй сінее неба I сее непрыветы: То студзяць яе зімы, То паляць яе леты.

44 Янка Купала, Збор твораў у шасиі тамах. Вершы $i$ паэмы 1911-1917, Мінск 1961, "Нашай Ніве", т. 3, с. 73-74. 
Обламує і вітер

Гілля їй без сумління,

I річка підмиває

Розложисте корінне.

Утіха лиш - пташині

Пісні дзвінкі, сріблисті...

Жалобу туги носить,

Як скине з себе листє.

От так то дні проходять

Всі низкою страшною.

Шумить вільха і тужить

Над річкою сумною. ${ }^{45}$
A vítr ulamuje

haluzky bez ustání,

a říčka podemílá

žilovaté kořání.

Potěší se, když ptáčci zpívají v jarním čase, žalobné žaly snáší, když z listí vysvléká se.

Dny mnohé přecházejí a nesou smutek samý. Smuteční olše šumí nad říčkou pod skalami.
Абломлівае вецер

Галіны без сумлення,

Падточывае рэчка

Жылястае карэнне.

Пацешыцца, як птушкі Пяюць вясной агнісце; Жалобу жаляў носіць, Як раздзяецца з лісцяў.

Дні многія праходзяць, Найбольш непагадліва, Шуміць маркотна вольха Над рэчкаю бурлівай ${ }^{46}$.

Для большей наглядности, графически отличающиеся выражения иллюстрируют, что украинская версия в отдельных элементах отличается от оригинала, в то время как перевод Тихого семантически более точен: напротив украинского слова «сушать ї̈ ноги» стоит белорусское «Аброслая» и чешское «оbrostlá», подобно - «суховї» против «леты» и «léto», «Розложисте» против «Жылястае» и «žilovaté» итд., в чешском варианте «žalobné žaly» сохранена даже аллитерационная фигура «Жалобу жаляў», тогда как в украинском варианте - «Жалобу туги».

Из трёх переводов стихотворений Янки Купалы «Ольху» можно считать наиболее удачным, жаль, что в межвоенное время это стихотворение не было обнародовано, ибо в чешской среде оно представило бы устоявшийся образ Купалы не только как барда-борца и критика социальных и национальных отношений белорусов, но и тонкого ценителя природы и поэта элегической лирики.

Свои переводы стихотворений Я. Купалы Тихий подарил в 1964 году литературному музею народного поэта в Минске. Подарок вызвал спонтанную реакцию в белорусской печати, а сам переводчик сделал две вырезки коротких сообщений и приложил их к остальным белорусским материалам, которые были целиком переданы им пражскому Литературному архиву Памятника национальной письменности и сегодня доступны в его персональном фонде (фонд Тихий [см. прим. 3]).

Несколько интересных подробностей содержится в заметке «Падарунак чэхаславацкага прафесара», поэтому привожу её полностью:

45 Янка Купала, Вільха. Пер. Микита Шаповал. "Літертурно-науковий вісник" ХІІ, 1909, т. 47, кн. 9, с. 511; доступно тоже электронно: http://www.ukrlib.com.ua/books-zl / printthebookzl.php?id=224\&bookid=10\&sort=1 [on-line 08-08-2016].

46 Янка Купала, Збор твораў у шасиі тамах. Вершы $і$ паэмы 1904-190\%, Мінск 1961, Вольха, т. 1, с. 72. 
Свае переклады вершаў Янкі Купалы, зробленыя амаль 30 гадоў назад, прыслаў у літаратурны музей народнага паэта Беларусі прафесар Францішак Ціхі з Прагі.

У матэрыялах, прысланых у Мінск, ёсць пераклады вершаў "А хто там ідзе?", "Вольха", "Маладая Беларусь", "Перад віселіцай" 47 і некаторыя іншыя. Яны дазваляюць больш дакладна ўстанавіць акалічнасці знаёмства аматараў літаратуры ў Чэхаславакіі з творчасцю Янкі Купалы.

Працы прафесара Францішака Ціхага і яго пераклады твораў Купалы з'яўляюцца значным укладам у развіццё беларуска-чэшскіх літаратурных і культурных сувязей ${ }^{48}$.

В пражском наследии Тихого находится ещё один уникальный документ, связанный с темой этой статьи - машинопись сценария (переводы с сопроводительным комментарием) радиопередачи «Полчаса белорусской поэзии», в которой отмечено, что Янке Купале (1882-1942) «сегодня пятьдесят два», и можно уверенно датировать этот факт промежутком между июлем 1934 и июлем 1935 года. Осуществилась ли эта передача, точно утверждать не могу, но это довольно вероятно, если не правдоподобно.

На 4,5 страницах Тихий кратко описал белорусско-польско-русские отношения («Сегодня восточная часть Белой Руси является самостоятельной республикой в рамках СССР со столицей - городом Минск. Насчитывает шесть миллионов жителей, почти на $100 \%$ белорусской национальности. Западная часть этнографической белорусской области находится сегодня на территории Польши. (...) Поляки в прошлом всегда были рады присоединить к себе белорусов. (...) Русские впервые обратили внимание на своих белорусских братьев после польского восстания 1863 г. Целый ряд учёных, в большинстве своём белорусского происхождения, изучал язык, публиковал песни и пословицы. (...) Но не только России, но и полякам Белая Русь дала много знаменитостей» 49 ). Занимаясь историей чешско-белорусских литературных

47 Ошибочно: должно быть Перад вісельняй, см. прим. 44.

48 Падарунак чэхаславачкага прафесара, "Звязда" XLVIII, 1964, № 223 (13595), 23. 9.; краткое сообщение на русском языке Подарок чехословацкого профессора в тот же день опубликовано в газете "Советская Белоруссия".

49 F. Tichý, Bílá Rus jest krásný a úrodný kraj... [Белая Русь красивый и плодородый край...], недатированная машинопись в кол. 4, 5 стр., написанная в 1934-1935 г. в качестве сценария радиопередачи, s. 1, фонд Тихий (см. прим. 3). - Оригинал: "Dnes je východní část Bílé Rusi samostatnou republikou v rámci SSSR s hlavním městem Minskem. Má šest milionů obyvatel, téměř na $100 \%$ běloruské národnosti. Západní část etnografické oblasti běloruské jest v dnešní Republice polské. (...) Poláci si v minulosti Bělorusy vůbec rádi prrivlastňovali. (...) Rusové se rozpomenuli na své běloruské bratry 
отношений, Тихий уделил особое внимание пражскому изданию белорусской библии в переводе Франтишка Скорины, а позднее к своей подборке из белорусской поэзии написал, выразив свою позицию по отношению к проблематике развития новой белорусской письменности, следующее:

Сегодня мы хотим познакомить вас не только со старой, но и с новейшей поэтической белорусской культурой. Я выбрал для вас из своей белорусской антологии, из собственных рукописей переводов современной белорусской поэзии семь поэтов старшего и младшего поколений и взял из их творчества наиболее выразительные произведения. Тешу себя надеждой, что образ, который будет формировать в вашей душе наши полчаса белорусской поэзии, не будет неясным и неопределённым.

Разрешите мне, однако, предупредить вас об одном обстоятельстве. Белорусская поэзия всего 19-го века есть не что иное, как стихи самоучек, отзвук народных песен и подражание. Белорусская литература вообще была в начале нашего века региональной и диалектической [подразумеваются письменные диалекты - M. Ч.]. После революции 1905 года здесь начинается быстрое движение ${ }^{50}$.

Главная роль была, естественно, отведена Янке Купале как основателю и автору народного гимна:

Наибольшие заслуги и размах относятся к поэту Янке Купале, собственно говоря, Ивану Луцевичу. Ему ныне пятьдесят два года, он родился в Минской области. Его отец был управляющим хозяйством, и сам он тоже занимался сельским хозяйством. Систематического школьного образования он не получил - т.е. он тоже самоучка - но серьёзно занимался самообразованием, а потом посещал в качестве вольнослушателя частные лекции в Петрограде. В 1913 году он переезжает из Петрограда в Вильно и становится редактором белорусского журнала «Наша Нива». Военные

teprve po polském povstání r. 1863. Celá řada učenců, většinou běloruského původu, zkoumala jazyk, vydávala písně a přísloví. (...) Avšak nejen Rusům, ale i Polákům dala Bílá Rus mnoho znamenitých mužů".

50 Там же, с. 2. - Оригинал: "My vás dnes chceme seznámiti nikoli se starou, ale s nejnovější básnickou kulturou běloruskou. Vybral jsem pro vás ze své běloruské antologie, ze svých rukopisných překladů z moderní poezie běloruské, sedm jsem současných básníků starší i mladší generace. U jednotlivých jmen vybral jsem opět čísla nejvýraznější. A tak se těším nadějí, že obraz, který bude ve vaší duši kresliti naše půlhodinka běloruské poezie, nebude nejasný a neucelený.

Dovolte však, abych vás napřed ještě upozornil na jednu věc. Básnictví běloruské v celém 19. stol[etí] není nic jiného než verše samouků, ohlasy písní lidových a epigonství. Literatura běloruská byla vủbec ještě na počátku našeho století regionalistickou literaturou dialektickou. Teprve po revoluci r. 1905 nastává tu prudký ruch”. 
годы он прожил в Москве, а после революции обосновался в Минске. Правительство присвоило ему звание «белорусского народного поэта» и издало собрание его сочинений.

Хотя Купала писал стихотворный эпос, сценарии и прозу, он является признанным лириком - и лириком объективным, народным поэтом-будителем. Было необходимо пробудить народное сознание широких слоёв общества, и Купала пишет пламенные социально окрашенные призывы к родине. Среди своих земляков он особенно прославился как автор национального белорусского гимна «А кто там идёт?». Послушайте, пожалуйста, его текст [А хто там ідзе?].

Внутренний народный огонь и достойное внимания чувство звучат в стихе: «Молодая Белоруссия» [Маладая Беларусь].

Когда происходили торжества по случаю десятой годовщины Белорусской Советской Республики, Купала написал ряд торжественных стихотворений. Послушайте, пожалуйста, одно из них, в котором сочетаются народное звучание и художественная форма: «Из юбилейных настроений» [3 угодкавых настрояў].

А на прощание с Купалой - ещё выражение его веры в лучшее будущее его народа: «Не погаснут...» [«Нашай Ніве»] ${ }^{51}$.

Передача продолжалась примерами из творчества Якуба Коласа (Из пэмы «Symon Muzyka» [Сымон Музыка - O край родны, край прыгожы], «Рřed bouří» [Перед бурей; “Šed' i hloub, jež konce nemá, / svatá tiš

51 Там же, с. 3. - Оригинал: "Největší zásluhu o tento rozmach a ruch má básník Janka Kupala, vlastně Ivan Lucěvič. Je to dnes dvaapadesátník, rodák z minského kraje. Jeho otec byl hospodářským správcem a on sám se také věnoval zemědělství. Soustavného vzdělání školského se mu nedostalo - tedy i on je samouk -, avšak získal si značné znalosti sebevzděláním, později také jako posluchač soukromých kursů v Petrohradě. Z Petrohradu odchází r. 1913 do Vilna jako redaktor běloruského časopisu "Naša niva". Válku prožil v Moskvě, po revoluci se usadil v Minsku. Vláda mu udělila titul "běloruského národního básníka" a vydala mu krásně jeho sebrané spisy.

Kupala psal sice též veršovanou epiku, divadlo i prózu, ale je vyslovený lyrik. A tu především lyrik objektivní, básník buditel. Bylo třeba probouzeti národní povědomí v širokých vrstvách, a tak Kupala píše plamenné výzvy vlastenecké, zabarvené sociálně. Mezi svými krajany proslavil se zvláště jako autor národní hymny běloruské. Poslechněte si laskavě její text:

Kdo to kráč́ sem... [А хто там ідзе?]

Niterný zápal národní, ale i pozoruhodný smysl formální zní z básně další:

Mladá Bělorus [Маладая Беларусь]

Když se před 5 lety oslavovalo desáté výročí Běloruské sovětské republiky, napsal Kupala řadu oslavných básní. Poslechněte si laskavě jednu z nich, spojující šủastně lidový názvuk s uměleckou formou:

$Z$ jubilejních nálad [3 угодкавых настрояў]

A na rozloučenou s Kupalou ještě jeho vyznání víry v lepší budoucnost jeho národa: Nepohasnou... ["Нашай Ніве"]". 
a zpraha němá..." $\left.{ }^{52}\right]$, «K desátému výročí Běloruské sovětské socialistické republiky» [K десятой годовщине образования Белорусской Советской Социалистической Республики; "Čas míjel. Ztajený a němý / v těch bažinách a pustách těch..."]), одним в иелом нереволюиионньм стихотворением Цишки Гартного «Běloruska» [Беларуска], двумя стихотврениями, в которых вы почувствуете музыкальные элементы и мотивачию, Андрея Александровича («Struna» [Струна], «Před budoucností» [Перед будущим; "Po moři jsme pluli v dáli, / lod' naši chvátil rozzuřený vzdor..."]) и более обширной с современным экспрессионистским оттенком поэме Алеся Дудара «Záŕí» [Сентябрь; "Tupou dálkou probíjí se / úder větru oslizlého..."], и в конце достигла апогея в поэтическом произведении Николая Чарнушевича [т.е. Миколь Хведаровича], удивляющего своей философичностью, «Žitné úsměvy» [Ржаные улыбки; "Slyšel jsi, jak žito směje se / v smetanově bělavé své vousy..."].

Все переводы Тихого из белорусской литературы для наглядности можно показать в списке авторов, разложенных в алфавитном порядке (наряду с опубликованными привожу и неопубликованные тексты из пражского наследия переводчика; фонд Тихий [см. прим. 3]):

1. Александровіч Андрэй Іванавіч (у Тихого Andrej Aleksandrovič; 1906-1963) Переводы не опубликованы.

В наследии:

«Před budoucností» ["Šly roky. Po moři jsme pluli v dáli, / lod' naši chvátil rozzuřený vzdor..."], «Struna» [Струна]

2. Гартны Цішка, собст. имя Зміцер (Змітро) Хведаравіч Жылуновіч (у Тихого Ciška Hartný; 1887-1937)

«Dojdeme, synku» [Дойдзем, сынок], "Dělnická rovnost" (Brno) I, 1929, č. 1, s. 6, 6. 1 .

«Dojdeme, synku» [Дойдзем, сынок]. Z knihy Třísky na vlnách, "Rudé právo" X, 1929, č. 6, 6. 1., př́l. Dělnická besídka, s. 2.

«Dojdeme, synku» [Дойдзем, сынок], "Obrana / Defense" (New York) XX, 1929, č. 17.

В наследии:

«Běloruský národ» [Беларускі народ], «Běloruska» [Беларуска], «Delegátka» [Дэлегатка]

52 Стихотворения, белорусский оригинал которых мне не удалось найти, характеризую, по крайней мере, двумя первыми стихами. 
3. Гурло Алесь (Аляксандр) Кандратавіч (у Тихого Aleś Hurlo; 1892-1938)

«Zápasníkovi» [Барацьбіту], "Reflektor" V, 1929, č. 5, s. 60.

«Zápasníkovi» [Барацьбіту] - «Běloruská selka» [Беларуская сялянка] - «Na mоři» [Заблішчалі ў цёмнай далі маякі] - «Žnečka» [Жняя] - «Životní zápas» [Змаганне за жыццё53] - «Město» [Горад], "Slovanský přehled" XXX, 1938, s. 403-406.

В наследии:

«Zápasníkovi» [Барацьбіту], «Sedlák» [Сялянін], «Běloruská selka» [Беларуская сялянка], «Na mоři» [Заблішчалі ӱ цёмнай далі маякі], «Žnečka» [Жняя], «Životní zápas» [Змаганне за жыццё], «Město» [Горад]

4. Дудар Алесь, собст. им. Аляксандр Аляксандравіч Дайлідовіч (у Тихого Aleś Dudar; 1904-1937)

«Stíny» [Ценi], "Národní osvobozenî" VI, 1929, č. 55, 24. 2., příl. Hodina, č. 9 , s. 1 .

«Květen obsypává bílý sad» [Асыпае чэрвень белы сад5], "Země" XI, 1929-1930, č. 3, s. 103-104, 6.12.1929.

«Revoluce» [Навальніца ${ }^{55}$ ], in: M. Iljaševič, «Bělorus a Bělorusové». Český čtenář 21, sv. 6-7, Praha 1930, s. 103-104.

«Stíny» [Ценi], in: M. Iljaševič, «Bělorus a Bělorusové». Český čtenář 21, sv. 6-7, Praha 1930, s. 105.

В наследии:

«Záŕí» I-II. ["Tupou dálkou probíjí se / úder větru oslizlého..."], «Květen obsypává bílý sad» [Асыпае чэрвень белы сад], «Stíny» [Ценi], «Revoluce» [Навальніца]

5. Колас Якуб, собст. им. Канстанцін Міхайлавіч Міцкевіч (у Тихого Jakub Kolas; 1882-1956)

«Starosta» [Стараста], "Domov a svět" II, 1928, č. 36, s. 2 [имя автора в форме Taras Hušča (= Jakub Kolas)].

53 Исправляю ошибочное утверждение белорусского исследователя, что речь шла о стихотворении Жыциёвы бой, из которого были приведены цитаты со ссылкой на избранные стихотворения Гурло; сравн. М. І. Чмарава, Шляхі ўзаемнага пазнання, op. cit. (прим. 21), с. 114-115.

54 Исправляю ошибочное утверждение белорусского исследователя, что речь шла о стихотворении Кветкі абсыпающь бель сад, сравн. М. І. Чмарава, Шляхі ўзаемнага пазнання, ор. сіt. (прим. 21), с. 112.

55 М. I. Чмарава неточно указала вместо названия только инципит "Праскакаў над бяздоннем вякоў...", сравн. М. І. Чмарава, Шляхі ўзаемнага пазнання, ор. cit. (прим. 21), с. 112. 
Из поэмы "Symon Muzyka" [Сымон Музыка - О край родны, край прыгожы], "Literární noviny" III, 1929, č. 19 (59), s. 3, 31. 10.

Из поэмы "Symon Muzyka" [Сымон Музыка - О край родны, край прыгожы], in: M. Iljaševič, «Bělorus a Bělorusové». Český čtenář 21, sv. 6-7, Praha 1930, s. 98-101.

«Starosta» [Стараста], in: M. Iljaševič, «Bělorus a Bělorusové». Český čtenáŕ 21, sv. 6-7, Praha 1930, s. 112-116 [имя автора в форме Taras Hušča (= Jakub Kolas)].

В наследии:

Z básně "Symon Muzyka" [Сымон Музыка - O край родны, край прыгожы], «K desátému výročí Běloruské sovětské socialistické republiky» ["Čas míjel. Ztajený a němý / v těch bažinách a pustách těch..."], «Před bouří» ["Šed'i hloub, jež konce nemá, / svatá tiš a zpraha němá..."], «Husy» [Гусі]

6. Купала Янка, собст. им. Іван Дамінікавіч Луцэвіч (у Тихого Janka Kupala; 1882-1942)

«Z jubilejních nálad» [3 угодкавых настрояў - 1.], "Národní osvobození" V, 1928, č. 299, 28. 10., př́l. Hodina, č. 44, s. 2.

«Prý zpívám» [Вы кажаце...], "Čin” I, 1929-1930, č. 50, s. 1193, 9.10.1930.

«Z jubilejních nálad» [3 угодкавых настрояў - 1., 5.], in: M. Iljaševič, «Bělorus a Bělorusové». Ceský čtenář 21, sv. 6-7, Praha 1930, s. 101-103.

«Prý zpívám...» [Вы кажаце...] - «Tu stojím, ruce křížem» [Злажыy̆шы рукі...] - «Jubilejní nálada» [3 угодкавых настрояў - 5.], "Země” XIV, 1933-1934, č. 2-3, s. 78-80, 31.1.1933.

«Kdo to kráčí sem?»[А хто там идзе?], "Národní osvobození" XII, 1935, č. 192, 18. 8., př́l. Hodina, č. 27, s. 11.

«Prý zpívám» [Вы кажаце...], "Národní osvobozenî" XII, 1935, č. 234, s. $1,8.10$.

«Mladá Bělorus» [Маладая Беларусь], "Slovanská revue" I, 19341935, č. 5, leden 1935, s. 25.

В наследии:

«Z jubilejních nálad» [3 угодкавых настрояў $-1 .+5$.], Kdo to sem kráčí? [А хто там идзе?], «Mladá Bělorus» [Маладая Беларусь], «Pod šibenicí» [Перад вісельняй], «Prý zpívám» [Вы кажаце...], «Tu stojím, ruce křížem» [Злажыўшы рукі...], «Nepohasnou» [«Нашай ніве» («Не загаснуць зоркі ў небе»)], «Olše» [Вольха]

7. Машара Міхась (Міхаіл Антонавіч) (у Тихого Michaś Mašara; 1902-1976) 
«Na přelom» I-III. [На пералом... ${ }^{56}$ - «Bez názvu» [Без назвы; «Чуеш брат малады, / Як бурліў і звіняч веснашум?»], "Slovanský přehled" XXIX, 1937, s. 41-43.

8. Моркаўка Аркадзь Андрэевіч (у Тихого Arkadź Morkauka; 1900-1957)

«Pad na kolena den...» [«Паў на калені дзень...»], "Země" X, 19281929, č. 6, s. 199-200, 28.2.1929 [имя автора в форме Arkadž Morkaňka].

«Kvetoucí sádek ran a boláčků...» [«Квяцісты палісаднік ран і болек...»], "Země" X, 1928-1929, č. 7, s. 234-235, 30.3.1929.

«Stěny» [Сцены], "Národní osvobození" VI, 1929, č. 55, 24. 2., příl. Hodina, č. 9, s. 1.

«Stěny» [Сцены], in: M. Iljaševič, «Bělorus a Bělorusové». Český čtenář 21, sv. 6-7, Praha 1930, s. 106.

В наследии:

«Kvetoucí sádek ran a boláčků» [«Квяцісты палісаднік ран і болек...»], «Pad na kolena den» [«Паў на калені дзень...»], «Stěny» [Сцены], «Křik ulice» [Крык вулицы]

9. Хведаровіч Мікола, собст. им. Мікалай Фёдаравіч Чарнушэвіч (у Тихого Nikolaj Čarnuševič; 1904-1981)

«Dvojhlasně» ["Jen vzbud' mne, vzbud' mne, z rána, za raníčka, / - z rána, za raníčka slzy na kalině...”], "Země” XI, 1929-1930, č. 1, s. 19-20, 26.9.1929.

В наследии:

«Dvojhlasně» ["Jen vzbud' mne, vzbud' mne, z rána, za raníčka, / - z rána, za raníčka slzy na kalině...", *** ["Budu, budu hvězdy síti / nad kalinou uplakanou..."], «Žitné úsměvy» ["Slyšel jsi, jak žito směje se / v smetanově bělavé své vousy..."]

Само собой разумеется, эти тексты заслуживают более подробного анализа, но из-за ограничений объёма текста обратим внимание, по крайней мере, на проблемы Тихого с цензурой и на неизвестный до сих пор (хотя и изданный) перевод прозы.

На проблемы Тихого с чехословацкой межвоенной цензурой (во время т. наз. Первой республики) впервые указал Вацлав Жидлицкий в обширной статье, посвящённой чешско-белорусским литератур-

56 М. І. Чмарава исказила название "На пераломе", сравн. М. І. Чмарава, Шляхі ўзаемнага пазнання, ор. cit. (прим. 21), с. 115; стихотворение из сборника Машары На прадвесні, Вільня 1935, с. 10-12. 
ным отношениям, и на основании письменного подтверждения участника событий отметил, что «Nevolnice» Дудара и «Krok ulice» Mapкоуки были изъяты, а на страницах коммунистической газеты «Rudé právo»57 остались только имена и названия произведений и пустье места $a^{58}$. В этой информации есть несколько неточностей, фактически ошибок: прежде всего, фамилия второго упомянутого поэта Моркайка (а не Маркоўка), далее, после вмешательства цензуры остались только имена авторов («Ales Dudar» и «Arkadz Morkauka») и ошибочные инициалы переводчика «С белорусского языка перевёл Ф. Ф.» [вме-

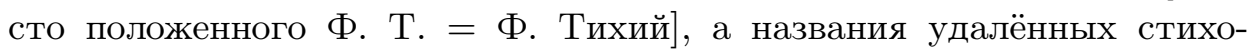
творений отсутствовали. По материалам наследия Тихого мы можем определить, что в случае Дудара речь шла об опубликованном позже (см. выше) переводе стихотворения «Revoluce» (Навальніца) (Жидлицкий, видимо, не смог прочитать рукописное сообщение Тихого, а информацию не проверил, поэтому прочитал ошибочно, как «Nevolnice», хотя Тихий использовал или чешское название «Revoluce», или написанное латинскими буквами название оригинала «Navalnica»), а в случае, относящемся к Моркаўке, речь шла о ранее неопубликованном переводе «Křik ulice» [т.e. Крик улицы] (Жидлицкий опять неточно прочитал плохо читаемый почерк Тихого как «Krok ulice» [т.е. Шаг улицы] ).

Перевод аллегорического стихотворения Дудара следующим образом был оценен Мажейко, который заметил, что переводчик заменил лексему «навальніца» (т.е. «буря») на более выразительное и конкретное - «revoluce»: Звязань з прагрэсіўньлі коламі Чэхаславакіі, прафесар Франиішак Ціхі сваёи творчасцю ўдзельнічаў у баращьбе супраць уладьг капіталу, за правь рабочага класа. Выбар творау для перакладу дыктаваўся часта палітьчнымі матьввамі. (...) Цікава прасачьць, як перакладчьк праясняе для свайго чьтача алегорыю беларускага паэта, i, адступаючь ад свайго правіла, мяняе ўсюды слова "навальніиа" на "рэвалючью", а вьграз “закон - наканиьл нажа" на значна больш адпаведнае сэнсу ўсяго верша - "закон на штькку"59.

57 Cpaвн. "Rudé právo" X, 1929, č. 36, 10. 2., příl. Dělnická besídka, s. 1.

58 V. Židlický, Př́spěvky k dějinám česko-běloruské vzájemnosti, "Slavia" XXIX, 1960, s. 212-234 (cit. 232).

59 А. Мажэйка, Беларуская літаратура ў чэшскіх перакладах, ор. cit. (прим. 21), c. 111-112. 
Его мнение почти дословно переняла Чмарава, только лишь с полемическим дополнением, что, подбирая тексты для перевода на чешский, Тихий не руководствовался идеологическими доводами, и с окончательным примечанием о цензуре: Цэнзура не раз здымала з газетных палос творы беларускіх паэтаў у перакладзе Ф. Ціхага. Гэта было ў значнай ступені абумоўлена тыл, што иікавасиь перакладчыкаў $і$ крытыкаў да беларускай літаратурь ўспрымалася ў Чэхаславакіi часта як прасавецкая прапаганда, што значна ўлльвала на актыўнасиь міжлітаратурнага ўзаемадзеяння $і$ асаблівасиі рэџэпиыібі.

С этой формулировкой полностью согласиться нельзя: это правда, что цензуру поразила публикация некоторых переводов как проявление просоветской пропаганды или как открытый призыв к восстанию против государства (революции), но по отношению к Тихому мне не известен какой-либо ещё подобный случай. Прежде чем делать столь радикальные выводы, следует быть внимательным и подтверждать свои слова библиографическими ссылками.

Как интересный факт, можно привести исходный чешский вариант как раз цитированной Мажейко второй строфы, которая отличается от опубликованного позже варианта более точным соответствием исходному тексту (за «закон - на канцы нажа» стояло изначально, из-за порядка слов, относительно неестественное stálo původně kvůli "zákon - nože na hrotu", изменённое в корректуре на окончательное "zákon - na bajonetu" [что соответствовало бы белорусскому «закон - на штыку»]), хотя и переводчику не удалось сохранить изначально чередующуюся рифму $a b a b$ белорусского оригинала - рифма изменена на обрывающийся $a b c b$ (выделено - М. Ч.):

$\begin{array}{lll}\text { Навальніца } & \text { Revoluce [печ. вариант] } & \text { Revoluce [рукопись] } \\ \text { Што ні крок - агонь і пажар, } & \text { Co krok, to oheň, požáry, } & \text { Co krok, to oheň, požáry, } \\ \text { I старому - у сэрца ўдар. } & \text { a co je staré, tomu zmar. } & \text { a co je staré, tomu zmar. } \\ \text { I закон - на канцы нажа. } & \text { A zákon - na bajonetu. } & \text { A zákon - nože na hrotu. } \\ \text { I не страшны ні бог, ні цар. }{ }^{61} & \text { A není strašný bůh ni car }{ }^{62} . & \text { A není strašný bůh ni car. }\end{array}$

Перевод стихотворения Моркаўки «Křik ulice» (Крык вуліцы) из сборника «Дым жыцця» (1928) очень интересен и, собственно, совершенно неизвестен, поэтому я его здесь впервые представляю (выделено $-M$. Ч.):

60 М. І. Чмарава, Шляхі ўзаемнага пазнання, ор. cit. (прим. 21), с. 112.

61 Алесь Дудар, Вежа. Вершы $і$ паэмь, Мінск 1984, с. 30.

62 Aleś Dudar, Revoluce, in: M. Iljaševič, Bělorus a Bělorusové, op. cit. (прим. 36), s. 103. 
Крык вуліиьь

Агонь і кроў. Як пчолы, кулі

Са свістам лётаюць ля вух. Наш дзень прышоў, - ой гулі-гулі Паўстань, спагарджаны наш дух!

Над намі кпілі, здзек над намі

Тварылі ўсе, забыўшы грэх. Цяпер мы робім над панамі Апошні суд, суд не на смех...

Агонь і кроў - вось наша кара. Няхай дрыжыць і гіне кат! Наш час - ня сон, наш час - ня мара, Ня будзе пан і сонцу рад!

Упаў таварыш... Вянок славы Ён трымае ў лепшы час.

Няхай смяюцца ваўкадавы, Што меней стала, меней нас.

Гараць дамы, гараць архівы, А ў іх - здабыткі ўсіх вякой. Ну што-ж? Затое палахлівых Ня будзе духу йржавых кой!

Гэй, хто ня уммёр, гэй, сябар працы! Бяры аружжа і - ̈у агонь, Каб адабраць усе палацы, Што паўзняла твая далонь!63
Krik ulice

Ohen̆ a krev. Jak včely kuli lítají kol, až přechází sluch. Přišel náš den, - oj, huli, huli, at'vstává zhrdaný náš duch!

Nám smáli se, nás vysmívali, a zapomněli, že to hřích. Ted' my jsme pány na soud vzali, soud poslední to, žádný smích...

Oheň a krev - v tom naše msta je. At' třese se, at' zhyne kat! Náš čas tu - žádný sen a taje, pán nebude na světě rád.

Nám padl soudruh. Vínek slávy on odnáší si v lepší čas. Jen at' se smějí vlci žraví, že míñ nás zbylo, míň že nás.

Již hoří dómy jako svíce a s nimi plody věků všech. A což? Však nebude již více duch spoután v rzivých okovech!

Soudruzi, hej, kdo mrtev není! Již do boje - v pěst každý zbraň! Paláce necht' jsou naše jmění, vždyt' týčila je naše dlaň!

За исключением не слишком удавшейся первой строфы, (по-чешски только гипотетическая форма множественного числа "kuli" вместо "kule" и производящее впечатление аффекта, несколько комичное и расплывающееся по смыслу междометие "huli, huli" - рифмованную пару Тихий взял без какой-либо адаптации к чешскому языку из белорусского) стихотворение имеет - кроме прочего, в связи с тем, что должно было выйти в коммунистической газете, - ясное послание протестовать и быть активными: обнищавший плебс решил свести счёты со своими угнетателями - господа и палачи ("at' zhyne kat!") названы кровожадными хищниками, - "голодными волками" (в оригинале "волкодавами", то есть собачьим племенем, используемым для отлова волков). Всё устаревшее и упадническое должно стать жертвой

63 А. Моркаўка, Дьлм жыция, Менск 1928, с. 33-34. 
очистительного огня ("Oheň a krev", "hoří dómy"; в одном месте метафора разгоревшегося конфликта выражена более прямо: “乌̈ агонь" - "в бой"), огонь, который является метафорой революции, каждый "soudruh" [т.е. товарищ] (здесь речь не идёт о массах, скорее об организованном сопротивлении), оставшийся в живых, должен поднять оружие и броситься в бой, который покончит с "rzivými okovy" [т.e. ржавыми оковами] и освободит униженный и оскорблённый ("zhrdaného") человеческий дух.

Кроме поэзии Тихий переводил частично белорусскую прозу. В исследовательской профессиональной литературе до сих пор в отношении деятельности Тихого упоминался только юмористический рассказ Якуба Коласа «Starosta» (Стараста), опубликованный дважды (сравн. выше). Уже несколько раз цитированный Мажейко сравнил, на основании нескольких чешских вариантов этого рассказа, подход Тихого с экономичной и лаконичной переводческой техникой известного пропагандиста белорусской литературы и писательницы Милады Вечержовой (1930-2004) и пришёл к выводу, что стремление к дословному переводу оказало Тихому в некоторых случаях медвежью услугу: $A$ скрупулёзнае следаванне за кожным словам арыгінала, імкненне выкарыстаць пры перакладзе нават блізкасиь кораняу роднасных моў часам падводзіџь перакладчька: "уставіўся ў адно месиа" зусім не значьъць: "стаў на адньцм месцьи", як у Ф. Ціхага ${ }^{64}$.

Однако мне удалось найти ещё один перевод, о котором Мажейко писал лишь как об одном из рассказов Цишки Гартного без указания конкретного названия и с добавлением, что рассказ опубликован в чешском нью-йоркском журнале «Obrana» 65 . Речь идёт о тексте «Dojdeme, synku» (Дойдзем, сынок), а кроме как в упомянутом журнале национального меньшинства американских чехов, рассказ был дважды опубликован и в чешской левой печати (сравн. выше). Короткий рассказ построен по принципу контраста обширных, золотеющих, и богатых урожаем житных полей (символ страны и материального обеспечения её жителей) и личным опытом белорусской женщины Маланки Груд, не имеющей пристанища (её муж воюет в Красной армии - действие происходит во время гражданской войны перед 1920 годом,

64 А. Мажэйка, Беларуская літаратура ў чэшкіх перакладах, ор. cit. (прим. 21), c. 114; намёк относится к ошибке Тихого: предложение «уставіўся у адно месца» он ошибочно перевёл как «стоял на одном месте», но правильное значение - «засмотрелся на одно место».

65 Сравн. там же, с. 115. 
когда был написан рассказ) и вынужденной бежать неизвестно куда со своим маленьким сыном из родного края от надвигающейся польской оккупации. Первоначальные картины рисуют природные пейзажи, переводчику удалось передать атмосферу поля на исходе лета и передать визуально содержание оригинала текста (выделено - М. Ч.):

Po obou stranách silnice, úzké, zarostlé zelenou travou, rozkládalo se nedohledné pole zlatistého žita. Vysoká, tlustá stébla jeho skláněla se hluboko pod tíží jadrných převislých klasů.

Úzké, vysoké meze, hustě poseté zastaralou jetelinou, zaschlým heřmánkem i poletavým hmyzem a mravenečky, rozrrezaly na dlouhé pruhy, tak se to z boku jevilo, celistvou, nedílnou rovinu.

Do dáli od silnice, na celé míle dokola, probíhal zrak lidský, ztráceje zelené nitky mezí v houští nachýlených klasů žitných.

V modrém, jako sklo průzračném povětř́, v nepohnuté, pokojné tišině poledního parna, vznášeli se nad plátnem niv, bezhlesně pějíce, rziví skřivánci. Z houštiny žita odpovídaly jim křiklavé křepelky a vzácní, plaší chřástalové.

Tam kdesi v dálce, po pravé straně silnice, slyšel jsi píseň žní. Známé nápěvky zpěvu žní vystupovaly z vonících klasů žitných, kolébaly se nad zlatem niv, a konečně, když se byly opojily vůní, zmlkaly v čistém povětří a v paprscích slunečních.

Vystřídaly je nové, ještě zpěvnější, ještě zvonivější a radostnější.

Už celé dvě hodiny šla mezi stěnami žita rovnou, vypuklou silnicí Malanka Hrudová se svým šestiletým synáčkem Michalkem.

Byla unavena jednak chůzí, jednak hořem, jež ji vyhánělo tou silnicí do cizího kraje, daleko od rodného místa, od známých osob, do nepovědomých poměrů, do nejasného života ${ }^{66}$.

Паабапал гасцінца, вузкага, заросшага зялёнай мяккаю мураўкай, ляжала неагляднае поле залацістага жыта. Высокія тоўстыя дубцы яго згіналіся да нізу пад цяжарам ядраных важкіх каласой.

Вузкія высокія межы, густа адзетыя застарэлым дзяцельнікам, засохшым рамонкам і павяўшым цюльпанам ды падушачкамі, разрэзвалі на доўгія стужкі, здавалася збоку, суцэльную непадзельную ройнядзь.

Далёка ад гасцінца, на цэлыя вёрсты вакол, прабягай узрок людскі, губляючы зялёныя ніткі межаў у гушчы нахіленых каласой жыта.

У сінім, празрыстым, як шкло, паветры, у нерухомай і спакойнай цішы паўднёвай пары насіліся над палатном ніӱ, неўгамонна пеючы, рэзвыя жаўранкі. 3 гушчару жыта ім адклікаліся крыклівыя перапёлкі ды рэдкія палахлівыя драчы.

66 Ciška Hartný, "Dojdeme, synku", "Rudé právo" X, 1929, č. 6, 6. 1., př́l. Dělnická besídka, s. 2 . 
Дзесьці там далёка, у правым канцы гасцінца, чулася пяянне жней. Знаёмыя меладыйныя гукі песень жніва вынікалі з пахучых каласой жыта, гойдаліся над золатам ніӱ i, нарэшще напіўшыся паху, змаўкалі $\ddot{y}$ чыстым паветры, у праменнях сонца.

Ix змянялі новыя, яшчэ болей пявучыя, яшчэ болей звонкія ды радасныя. Цэлых дзве гадзіны ўжо прайшла паміж сценаў жыта роўным выхілястым гасцінцам Маланка Груд з шасцігадовым сваім сынком Міхалкам. Яна была стомлена часткаю ад хады, часткаю ад таго гора, якое гнала яе гэтым гасцінцам у чужую краіну, далёкую ад роднага месца, знаёмых людзей, да няведамае справы, да няяснага жыцця ${ }^{67}$.

Даже мимолётное сравнение перевода с оригиналом свидетельствует о том, что Тихий стремился использовать лексическую близость обоих языков: «неагляднае поле» ("nedohledné pole"), «пад цяжарам ядраных важкіх каласоў» ("pod tíží jadrných převislých klasů"), «застарэлым дзяцельнікам» ("zastaralou jetelinou"), «прабягаў узрок людскі» ("probíhal zrak lidský"), «зялёныя ніткі межаў» ("zelené nitky mezî"), «над палатном ніӱ» ("nad plátnem niv"), «пяянне жней» ("píseň žní"); поэтически функционально выражены звуки пенья полевых птиц (правильно переведённое сочетание «палахлівыя драчы», здесь "plaší chřástalové", что не очень понятно для непрофессионала, но говорит о том, что у переводчика мог быть белорусский консультант). В некоторых местах имеется звуковая похожесть, но при этом и семантическая разница слов, напр., когда «у гушчы нахіленых каласой жыта» он перевёл довольно несообразно как "v houští nachýlených klasů žitných", а упомянутое соединение образно означает "в середине", "посреди"; в других местах проявилось переплетение со словацким языком, напр. когда «трэба зламаць іх загарадзь» он перевёл как "jejich zátvor se musí zlomit" (на словацком языке слово означает "závoru, petlici či vězení" и в современном чешском языке проявляется только в охотничьем жаргоне - «капкан, который закроется», хотя и существует как неодушевлённый архаизм в значении "uzavření", однако в прямой речи матери к ребёнку это выражение немыслимо; значение белорусского нейтрального слова шире - забор, ограждение, ограда. Достоин внимания и тот факт, что переводчик не хотел перегружать свой текст реалиями и русскую версту (примерно 1,07 км) заменил более привычной милей (примерно 1,6 км), потому что здесь речь шла не об определённом расстоянии, а о панораме.

67 Цішка Гартны, Насустрач сонцу. Выбраныя апавяданні, Мінск 1978, с. 57-60 (cit. 57). 
Чтобы достичь эмоционального сопереживания с читателем, Тихий направил свои усилия на соблюдение правильности перевода деминутивов (даже иногда заменяя в чешском языке нейтральный символ), которые как бы выражают детское восприятие и в то же время вызывают сопереживание с ребёнком и его матерью (которая, однако, вступает в действие с прямой речью, адресованной маленькому Михалку), несмотря на то, что в рассказе доминирует классический рассказчик в третьем лице: в речи рассказчика мы находим, напр., выражения "skřivánci" («жаўранкі»), "synáček" («сынок»), "uzlíček" («ворачак»), "cupkati" («трухаць»), "květinky" («кветачкі»), "žvatlat” («лепятаць»), "palouček" («паплавінка»), "raneček" («ворак»), "krajíček" («акрайчык»), "pomaloučku" («марудна»), в речи матери эмоциональные обращения "chudáčku" («нябожа мой»), "synáčku" («сынок»), "miláčku" («каханы», «даражэнькі»), "hošičku" («мілы») и другие уменьшительно-ласкательные слова, такие, как: "kousíček [půdy]" («палоска»), "políčko" («поле», «палоска»), "s tatínkem" («з бацькам») и т.д.

Сам Тихий этот перевод, видимо, ценил и упомянул о нём в своей поздравительной телеграмме Цишке Гартному по случаю его юбилея - 20-летия писательской деятельности:

Літаратурнае аб'яднанне "Польля". Менск

Таварышы!

У дзень, калі Цішка Гартны, паэта і адзін з першых публіцыстых Беларусі, канчае 20-ы год сваёй пісьменніцкай дзейнасці, далучаю і я свой голас да вашай радасці. Желаю, каб юбіляр і ў новым дзесяцігодздзі сваім запалам яшчэ больш раздзімаў бы ваша "Полымя".

Ушаноўваю разам з вамі гэты дзень ня толькі словам, але і ўчынкам. Пераклай адно апавяданне Гартнага, а таксама напішу аб ім у некаторыя нашы газэты.

3 таварыскім славянским прывітаннем

Праф. д-р Францішак Ціхі ${ }^{68}$

Возможное включение этого рассказа в антологию публикаций Ильяшевича «Bělorus a Bělorusové» было бы, однако, нежелательно, с учётом чехословацко-польских отношений: образ поляков-захватчиков белорусской земли мог только ухудшить и без того напряжённые отношения двух соседствующих стран.

Остаётся ещё упомянуть о белорусистских научных и популярных статьях Тихого. Первой из немногих работ этого характера была

68 "Полымя" VII, 1928, № 10, с. 241. 
рецензия на поэтическое произведение Я. Коласа «Сымон Музыка» (Менск 1925), в которой автор трактует поэму как попытку нарисовать субъективный портрет белорусских крестьян. Но эту аллегоричность он считает несколько туманной, сочетание реалистических элементов с романтическими - не слишком удавшимся художественно, с идеологическим налётом и некоторой искусственностью формы. Выбранный жанр (обширный эпос) он считает не подходящим: Произведение выказыьвает не только недостаток самокритики, но и недостаточную художественную дисчиплинированность в использовании поэтических средств. Большая часть содержания, при ограниченной одарённости, выпадает из рук автора ${ }^{69}$.

И напротив, Тихий оценивает виртуозный стих отдельных частей, соизмеренную композицию и особенно лирические вставки: Из всех лирических картин отличается прекрасная рапсодия "О край роднь, край прыгожь” (...), несомненно, достойная перевода 70.

В заключение рецензии Тихий касается общих черт так наз. окраинных литератур, к которым он относит и белорускую литературу. В то время как «материнская» русская литература может гордиться творчеством А. Блока, а «сестринская» литература украинская в произведениях П. Тычины стоит наравне с современными западно-европейскими течениями, Колас создаёт анахронизм, ограничиваясь в выборе материала корнями родной земли и обрабатывая их консервативным способом (хочет выразиться в духе изжитой традиции). В этом он близок в своём поступательном движении к эпической поэме "Dědův odkaz» (Завещание деда; 1879) чешского поэта Адольфа Гейдука (1835-1923), то есть к произведению, которое было актуально в зрелой чешской литературе 50 лет тому назад. Вся окраинная литература без исключения, по мнению Тихого, характеризуется наполненностью местным материалом и художественной пассивностью вплоть до упадничества, идёт ли речь о западной литературе (каталонская, провансальская, нижненемецкая) или о славянской (белорусская, кашубская, словацкая, серболужицкая, словенская).

69 F. Tichý, Jakub Kolas: Symon Muzyka... "Slovanský přehled" XVIII, 1926, č. 5 (květen), s. 392-393 (cit. 393). - Оригинал: "Báseň projevuje vůbec nejen nedostatek autokritiky, ale i nedostatek umělecké ukázněnosti v užívání básnických prostředkův. Básníku vymyká se při jeho omezeném nadání větší celek z rukou".

70 Там же; этот отрывок Тихий действительно перевёл позже (см. выше). - Оригинал: "Nad všechny ty četné lyrické mezihry vyniká překrásná rapsodie «O kraj rodny, kraj pryhožy» (...), která by rozhodně stála za překlad". 
Можно согласиться с констатацией белорусской исследовательницы М. И. Чмаравой, что Тихий ожидал от поэмы в целом чего-то иного, как в плане содержания, так и художественных средств: $A p b-$ ентуючься на мадэрнісцкія літаратурньля пльні свайго часу, ён не зразумеў $i$ не прыняу традыџыйнай народнай асновы коласаўскай паэмы, яе фальклорнай метафарычнасиі ${ }^{71}$. С другой стороны, следовало бы дополнить, что Тихий, будучи знатоком творчества Гейдука (написал о нём свою первую монографию), был столь же бескомпромиссен и по отношению к старшей чешской предшественнице поэмы Коласа - к бесспорно интереснейшему произведению Гейдука «Dědův odkaz», находя в нём якобы стихийное извержение лиризма, в котором эпические элементы носят характер лирических чувств, а произведение в целом является чем-то феерическим с тенденцией к какой-то неясной аллегории ${ }^{72}$. Тихий считает, что произведение категорически страдает изъяном, который разрушает почти всё поэтическое произведение - художественной недисциплинированностью: Из стихотворного произведения было бы можно выбросить не только челье стихи, но и челье строфы. И это относится $\kappa$ каждой части (в двойном же размере $\kappa$ части лиро-эпической), которая способна заменить эпическую стихию тоскливо экономичными художественными выражениями ${ }^{73}$.

В 1936 году в летние каникулы (июль и август) он отправился в исследовательское путешествие по украинским и белорусским землям, получив финансовую помощь от пражского Славянского института ${ }^{74}$. Изначально он предполагал посетить и Минск, но советские учреждения его туда не пустили, поэтому он побывал в Варшаве, познакомившись там с университетским профессором Романом Смаль-Стоцким (1893-1969) - и в Вильно, где познакомился с воспитанником Карлова университета Яном Станкевичем (1891-1976) и собирал материал для своей будущей работы, посвящённой развитию белорусского литера-

71 М. І. Чмарава, Шляхі ўзаемнага пазнання, ор. cit. (прим. 21), с. 113.

72 F. Tichý, Adolf Heyduk a jeho dílo, Praha s. d. [1915], s. 102-103.

73 Там же, с. 103-104. - Оригинал: "Z básně by šly šmahem vypouštěti ne celé verše, ale celé sloky. A to je chyba u každého díla, dvojnásob u díla lyricko-epického, které může nedostatek živlu epického nahrazovati jen úzkostlivou hospodárností v básnickém výrazu".

74 Cpaвн. Zpráva Dra Františka Tichého o studijní cestě po zemích ukrajinských a běloruských, vykonané s podporou Slovanského ústavu, "Ročenka Slovanského ústavu" IX, 1937 [za rok 1936], s. 69-70. 
турного языка 75 . Потом он посетил Львов и вернулся в Чехословакию через Черновцы и Ясину.

Для белорусоведческой деятельности Ф. Тихого имели большое значение многочисленные подаренные ему книги, которые он привёз с собой - кроме поэтических сборников Михася Машары, Максима Танка и Натальи Арсеньевой он получил работу варшавского профессора Ивана Огиенко «Розмежування пам'яток українських вид билоруських" (Жовква 1934), содержащую методику определения различий между старой украинской и белорусской письменностью. Этот труд Тихий рецензировал в престижном журнале «С̆asopis pro moderní filologii». Огиенко в своём повествовании антиципировал принцип литературно-языковой двойственности (у Д. Дюришина и его преемников эти принципы разработаны в теории «двудомности», «билитературности» и межлитературных общностей) определённых словесных выражений - если нельзя достоверно определить национальность автора, место возникновения письменного памятника или если его язык недостаточно выразителен, то можно предполагать принадлежность документа к совместному украинско-белорусскому наследию ${ }^{76}$.

По возвращении домой Тихий написал (кроме обоих текстов по языкознанию) ещё короткую работу об Алесе Гурло, задуманную как послесловие к небольшой подборке его стихов (см. выше). Несмотря на то, что талант Гурло, по мнению Тихого, ограничен по сравнению с двумя корифеями белорусской литературы Я. Купалой и Я. Коласом, его старательные четверостишия построены «очень солидно» с точки зрения рифмы и ритма, можно было бы даже говорить о формальной виртуозности, если это при появлении столь молодой литературы не парадоксально, но в целом значение его творчества уменьшается из-за смысловой плоскости и однообразия формы. Его художественный рост был прерван трагически - сначала он стал политическим изгнанником (здесь Тихий столкнулся со сталинскими репрессиями в Белоруссии, связанными с искусственным процессом над членами несуществующей организации «Саюз вызвалення Беларусі», направленным прежде всего против белорусской творческой и научной элиты - Гурло был наказан

75 Исследование, новаторское в чешской среде, опубликовано в след. году, сравн.: F. Tichý, Spisovný jazyk běloruský, (in:) Miloš Weingart [ed.], Slovanské spisovné jazyky $v$ době př́tomné, Dobrovského knižnice duchovědná, sv. 1, Praha 1937, s. 287-294.

76 F. Tichý, Др. Іван Огіенко: Розмежування пам'яток українських від білоруських, "Časopis pro moderní filologii" XXIII, 1936, s. 178-180. 
в 1931 году высылкой в Самару) и впоследствии (4 сентября 1938 года) скоропостижно скончался вдали от своего родного края ${ }^{77}$.

После Второй мировой войны Тихий мало занимался белорусистикой и, как мне удалось выяснить, опубликовал только две рецензии. В первой он писал о книге в высшей степени политической, отягощённой идеологией времени и о чешском переводе написанной по-русски работы Тимофея Сазоновича Горбунова (Цімафей Сазоновіч Гарбуноў [1904-1969] много публиковался на русском языке, но был по национальности белорус) "Воссоединение белорусского народа в едином советском социалистическом государстве" (Москва 1948). Рецензия вышла в специальном номере, прославляющем 35-ю годовщину так называемой Великой Октябрьской Социалистической революции, журнала «Slovanský přehled» (Славянский обзор), с которым Тихий был связан с 1906 года и на страницах которого опубликовал не один свой труд по болгаристике и другие переводы ${ }^{78}$. Чешскую версию книги сделала переводчица Вера Кованицова, и издание вышло под названиeм «Sjednocení běloruského národa $\mathrm{v}$ jednotném sovětském socialistickém státě» в Праге в 1951 году в Славянском издательстве (Slovanské nakladatelství). По отношению к чешким реалиям следует воспринимать эту публикацию как первую профессиональную монографию, изданную после изменения политических отношений (после февраля 1948 г.), а по отношению к Тихому интересно отметить, как рецензент приводит белорусско-польский конфликт к общему знаменателю со времён 20-х годов 20-го века:

Несмотря на то, что Белая Русь была с 25 декабря 1918 года независимой социалистической республикой в рамках Советского Союза, в 1921 году белополяки отторгли её западную часть - Гродненскую, Виленскую губернии и часть Минской.

Польша Пилсудского считала эти белорусские территории своей колонией (...) и жестоко подавляла их, как в экономическом, так и в культурном плане. Горбунов метко обозначил это как «разбойничью колониальную политику». Польские капиталисты планомерно и систематически ликвидировали белорусскую промышленность, и некоторые отрасли были за 20 лет ликвидированы полностью. (...) Прекрасные белорусские леса были стихийно вырублены и обогатили корыстолюбивых польских капи-

77 F. Tichý, Pozn. Aleś Hurlo... "Slovanský přehled" XXX, 1938, č. 10 (prosinec), s. 406407.

78 Более подробно см. М. Černý, Význam Slovanského přehledu pro českou (zejména literárněvědnou) bulharistiku, "Slovanský přehled" 101, 2015, č. 3, s. 627-671. 
талистов. (...) Горбунов справедливо называет, в этом отношении, бывшую Польшу «тюрьмой народов ${ }^{79}$.

Хорошо видно, на чьей стороне симпатии Тихого, а с этой точки зрения можно лучше понять, почему для перевода Тихий выбрал прозу «Дойдзем, сынок», чтобы она стала доступной чешскому читателю (сравн. выше).

Во второй рецензии автор критически оценивает чешский перевод русской монографии Евгения Семёновича Мозолькова (1909-1969), посвящённой жизни и творчеству Янки Купалы ${ }^{80}$, причём, главным образом, уделяет внимание недостаткам перевода Эвы Мрачковой (повествовательный текст) и Камила Беднаржа (поэтические примеры). Кроме определённой тяжеловесности и конкретных ошибок он уделяет внимание тому, что поэтические примеры были переведены с русского языка ${ }^{81}$, а не с оригинала, в связи с чем дело дошло до нежелательных перемещений в тексте и недоразумений, а у некоторых белорусских имён собственных осталась нежелательная русская форма ("Guslar", "Tetka" вместо "Husljar", "Cjotka")82.

Позже Тихий белорусистикой не занимался и отступил даже от издания своих старых рукописных переводов - эстафету взяло молодое поколение переводчиков, которое хотя и знало Тихого, но поверхностно и, кроме некоторых упоминаний, его не оценивало и практически забыло.

\footnotetext{
79 F. R. Tichý, Sjednocování běloruského národa v jednotném socialistickém státě, "Slovanský přehled" XXXVIII, 1952, č. 9 (listopad), s. 326-327. - Оригинал: "Bílá Rus byla sice od 25. prosince 1918 samostatnou socialistickou republikou v rámci Sovětského svazu, avšak v roce 1921 uloupili bílí Poláci západní její část: grodenskou, vilenskou a část minské gubernie.

Polsko Piłsudského považovalo toto běloruské území za kolonii (...) a krutě je utlačovalo jak na hospodářském, tak na kulturním poli. Gorbunov to přiléhavě označil jako «lupičskou koloniální politiku». Polští kapitalisté soustavně a plánovitě likvidovali běloruský průmysl, některá odvětví byla za dvacet let polské vlády zničena úplně. (...) Krásné běloruské lesy byly bez plánu zničeny ve prospěch kořistnictví polských kapitalistů. (...) Gorbunov právem označuje v té souvislosti bývalé Polsko jako «žalář národů»".

80 Русский оригинал Е. С. Мозольков, Янка Купала. Жизнь и творчество, Москва 1949, перевод на чешский J. Mozolkov, Janka Kupala. Život a dílo, přel. Eva Mráčková a Kamil Bednář, Praha 1954.

81 Подобным образом был переведён с русского языка, например, роман в стихах Коласа Рьъбакова хата (1947), сравн. J. Kolas, Rybářova chatrč, přel. Zora Beráková, Praha 1960.

82 F. R. Tichý, Pěvec socialistické Bílé Rusi, "Sovětská literatura" III, 1954, s. 752-754.
} 
Обширная переводческая и пропагандистская деятельность Франтишека Рута Тихого только подчёркивает ценный вывод белорусской исследовательницы Марины Чмаравой: Пры аналізе рэиэпџыл беларускай літаратурь ў міжваеннай Чехаславакіі трэба меиь на ўвазе, што колькасць надрукаваных твораў не адпавядае таму, што рэальна зроблена перакладчькамі, паколькі имат чаго страчана ${ }^{83}$. Одновременно будет к месту с удовольствием напомнить, что для белорусов тексты Тихого не потеряны, так как их автор ещё при жизни подарил их пражскому Литературному архиву (фонд Тихий, см. прим. 3), где они доступны для изучения. Вопрос только времени, когда эти материалы, столь важные для белорусистики, будут замечены исследователями из Белорусии и других стран, в которых развивается эта научная дисциплина.

Оценка переводческой деятельности Тихого является проектом, занимающим много времени, и нет возможности в короткой статье подробно проанализировать все существенные тексты. Следовало бы отыскать (в случае нескольких имеющихся неидентифицированных оригиналов) белорусские исходные тексты и, в идеальном случае, иметь зеркальное двуязычное издание всех переводов Тихого, сделанных им с белорусского языка. Только тогда проявится вся широта и глубина разносторонних начинаний Ф. Р. Тихого в этой области и будет возможно обогатить краткую - хотя меткую - характеристику того, что он был самылм актыўным перакладчыккам беларускай літаратуры на чэшскую мову ў 1920-1930-я гады ${ }^{84}$, новыми конкретными подробностями, деталями и более аргументироваными выводами.

\section{Приложение}

Франтишек Рут Тихий: «Мои белорусские воспоминания» ${ }^{85}$

Мои белорусские воспоминания довольно бедны. Когда интерес к белорусскому языку во мне пробудил мой приятель Микола Шиманка, я жил в Братиславе в Словакии, и счастье встретиться с поэтом

83 М. І. Чмарава, Шляхі ўзаемнага пазнання, ор. cit. (прим. 21), с. 111.

84 Там же.

85 F. Tichý, Mé běloruské vzpomínky, недатированная машинопись в кол. 2 стр., написанная, определённо, после 1955 года, фонд Тихий (см. прим. 3). - Оригинал: "Ме́ 
Янкой Купалой во время его приездов в Прагу минуло меня. Однако он выразил мне своё уважение, прислав два тома своих сочинений Збор твораў с таким посвящением: «Высокопаважному праф[есару] Ціхаму на добры успамін з пашанай Янка Купала. Менск 1.XII.1927».

Первые белорусские книжки я купил в 1923 г. в Ужгороде. Это были тетради Л. Родзевича [Леапольд Іванавіч Родзевіч, 1895-1938] Беларусь [(Вершы), Вільня 1922] и Досвіткі [(Драматычныя сцэнкі), Вільня 1922], отпечатанные в Вильно в 1922 г. Во время каникул 1936 года я хотел попасть в Минск для исследовательской работы, но советская миссия [т.е. консульство - М. Ч.] отказала мне в визе. Тогда я провёл несколько недель среди белорусов в Вильно. В продавце книг Яне Станкевиче я с приятным удивлением узнал доктора пражского

běloruské vzpomínky jsou chudičké. V době, kdy mne pro běloruštinu získal přítel Mykola Šymanka, žil jsem v Bratislavě na Slovensku, a tak jsem neměl štěstí setkat se s básníkem Jankem Kupalou za jeho pražských návštěv. Poctil mne však zásilkou obou dílů svého souboru Збор твораў s touto dedikací: "Высокопаважному праф[есару] Ціхаму на добры успамін з пашанай Янка Купала. Менск 1.XII.1927”.

První běloruské knížky jsem si koupil r. 1923 v Užhorodě. Byly to sešitky L. Rodzeviče Беларусь а Досвіткі, vytištěné ve Vilně 1922.

O prázdninách roku 1936 snažil jsem se dostat za studiem do Minska, ale tehdejší sovětská misse mi odepřela visum. Strávil jsem tedy několik týdnů mezi Bělorusy ve Vilně. V knihkupci Janu Stankěvičovi jsem s milým překvapením poznal doktora pražské university, vynikajícího filologa, který roku 1934 publikoval v pražské Slavii cквěлé noǔedнání Př́spěvky k dějinám běloruského jazyka na základě rukopisu Al-Kitab. Paní Stankěvičová byla Češka z Prahy, ve Vilně byla profesorkou na obchodní akademii. Byla s dětmi na prázdninové dovolené na venkově. Stankěvič byl doma sám, a tak mne pozval, abych u něho bydlel. Pozvání jsem vděčně přijal. Tím vděčněji, že jsem v Stankěvičovi našel znamenitého rádce a pomocníka ve svých běloruských studiích. Našel jsem v něm nadto dobrého, milého př́tele. Když jsme se loučili, daroval mi několik svých separátů. Do jednoho z nich, obsahujícího pojednání Stań badań nad klasyfikacja dialektów języka biatoruskiego (Balticoslavica II, 1936), napsal dedikaci "Драгому брату Чеху Сп[адару] праф[есару] п[ану] Францішу Ціхаму Аўтар. У Вільні 7.VIII.1936 г."

Plodem mých tehdejších studií bylo pojednání Běloruský jazyk spisovný, která vyšla ve sborníku Slovanské jazyky spisovné, vydaném prof. Milošem Weingartem v Praze 1938 [v tiráži 1937]. Prof. Antonín Dostál o této práci napsal: "O spisovném jazyce běloruském nemáme soustavných prací, proto je Tichého svědomitá studie velmi důležitá" (Č[eský] časopis historický [45], 1939, [č. 2], str. 285).

Při své tlumočnické práci si počínám tak, že zvolenou báseň si hlasitě přečítám tak dlouho, až se začne rýsovat nová básnická podoba v mé mateřštině. Mám za to, že zásluhou této metody se mi při Kupalově klasické básni $A$ xто maм idзe podařilo zachytit rytmiku originálu, což se nepodařilo ani mému předchůdci v té práci Adolfovi Cernému, ani následovníku Kamilu Bednářovi. Jsem přesvědčen, že mi to potvrdí také hudební text "běloruské hymny", který bohužel dosud neznám. Byl bych povděčen, kdybyste mne s ním seznámili.

P. S. Navrhuji, abyste "Běloruskou hymnu" vydali jako bibelotek ve světových řečech a s notami. V úvodě bude lze mj. citovat zajímavou zmínku o "Běloruské hymně" v listě M. Gorkého M. Kocjubins'kému z Capri 21.XI.1910". 
университета, замечательного филолога, который в 1934 году опубликовал в пражской Славии [Slavia, časopis pro slovanskou filologii] прекрасную работу Př́́spěvky $k$ dějinám běloruského jazyka na základě rukopisu Al-Kitab. Жена Станкевича была чешкой из Праги и преподавала в Вильно в торговой академии. Во время каникулярного отпуска она была с детьми за городом. Станкевич был дома один и пригласил меня пожить у него. Я с благодарностью принял его предложение. Тем более, что в Станкевиче я нашёл великолепного советчика и помощника в своих белорусских изысканиях. Кроме того, нашёл в нём милого доброго друга. Когда мы прощались, он подарил мне несколько своих работ. Одну из них - Stan badań nad klasyfikacja dialektów języka białoruskiego (Balticoslavica II, 1936), он сопроводил посвящением: «Дарагому брату Чеху Сп[адару] праф[есару] п[ану] Францішу Ціхаму Аўтар. У Вільні 7.VIII.1936 г.»

Результатом моих исследований стала работа Běloruský jazyk spisovný, которая вышла в сборнике Slovanské jazyky spisovné, изданном профессором Милошем Вейнгартом в Праге в 1938 [в книге 1937, печать, вероятно, опоздала] году. Проф. Антонин Достал написал об этой работе следующее: «О литературном белорусском языке у нас нет систематизированных работ, поэтому добросовестное исследование Тихого очень важно» (С̌ $[$ eský] časopis historický [45], 1939, [č. 2], str. 285).

Во время своей переводческой работы я начинаю с того, что перечитываю вслух выбранное стихотворение так долго, что начинает вырисовываться поэтическая копия на моём родном языке. Предполагаю, что благодаря этому способу мне удалось ухватить ритмику оригинала при переводе классического стихотворения Купалы $A$ xmo maм iдзе, что не удалось ни моему предшественнику Адольфу Черному, ни последователю Камилу Беднаржу. Я убеждён, что это будет подтверждено и музыкальным вариантом «Белорусского гимна», который мне до сих пор не известен. Я был бы благодарен, если бы Вы меня познакомили с ним.

P. S.

Предлагаю Вам издать «Белорусский гимн» с переводом на мировые языки и с нотами ${ }^{86}$.

В предисловии можно будет, кроме прочего, процитировать письмо М. Горького Коцюбинскому с Капри 21.XI.1910.

86 Такая антология действительно появилась, хотя и после смерти Тихого, и в ней содержатся переводы стихов Купалы на 82 языках; сравн. Я. Купала, A xто там iдзе? на мовах свету, укладанне В. Рагойшы, Я. Раманоўскай, Мінск 1983. 
ЛИ Т Е Р А Т У Р А

Гартны Ц., Насустрач сониу. Выбраныяя апавяданні, Мінск 1978.

Дудар А., Вежа. Вершы і паэмьи, Мінск 1984.

Купала Я., Вільха, пер. М. Шаповал, “Літертурно-науковий вісник” XII, 1909, т. 47 , кн. 9.

Купала Я., Збор твораў: У 6 тамах, т. 1, Мінск 1961.

Купала Я., Збор твораў: У 6 тамах, т. 2, Мінск 1961.

Купала Я., Збор твораў: У 6 тамах, т. 3, Мінск 1961.

Купала Я., Збор твораў: У 6 тамах, т. 5, Мінск 1962.

Мажэйка А., Беларуская літаратура ў чэшкіх перакладах, [in:] Н. С. Перкін [ed.], Садружнасиь літаратур, Мінск 1968.

Моркаўка А., Дьмм жьиция, Менск 1928, с. 33-34.

Мушинка М., Невтомний дослідник закарпатоукраӥнської культури Франтішек Тіхий.

Падарунак чэхаславацкага прафесара, “Звязда” XLVIII, 1964, № 223 (13595).

"Полымя" VII, 1928, № 10.

Tichý F., Др. Іван Огіенко: Розмежування пам'яток украӥнських від білоруськux, "Časopis pro moderní filologii" XXIII, 1936.

Чмарава М. І., Шляхі ўзаемнага пазнання: беларуская літаратура ў Чехаславакіi (1920-1945). Манаграфія, Магілеў 2004.

Dudar A., Revoluce, in: M. Iljaševič, Bělorus a Bělorusové, op. cit. (прим. 36).

Hartný C., "Dojdeme, synku", "Rudé právo" X, 1929, č. 6, 6. 1., př́il. Dělnická besídka.

Kupala J., Mladá Bělorus, přel. F. Tichý, "Slovanská revue" I, 1934-1935, č. 5, leden 1935.

Kupala J., Z jubilejních nálad, přel. F. Tichý. "Národní osvobození” V, 1928, č. 299, 28. 10., příl. Hodina, č. 44.

Tichý F., Adolf Heyduk a jeho dilo, Praha s. d. [1915].

Tichý F., Di̊o a osobnost Adolfa Černého, [in:] A. Frinta - F. Tichý [edd.], Slovanský přehled 1914-1924. Sbornik statí, dopisu a zpráv ze života slovanského. K šedesátým narozeninám Adolfa Černého, Praha 1925.

Tichý F., Jakub Kolas: Symon Muzyka..., "Slovanský přehled" XVIII, 1926, č. 5 (květen).

Tichý F. R., Pěvec socialistické Bilé Rusi, "Sovětská literatura" III, 1954.

Tichý F., Pozn. Aleś Hurlo..., "Slovanský přehled" XXX, 1938, č. 10 (prosinec). 
Tichý F. R., Sjednocování běloruského národa v jednotném socialistickém státě, "Slovanský přehled" XXXVIII, 1952, č. 9 (listopad).

Z Černé kroniky, "Rudé právo" XLVIII-XLIX, 1968, č. 96.

Židlický V., Přispěvky k dějinám česko-běloruské vzájemnosti, "Slavia" XXIX, 1960.

S T R E S Z C Z N I E

\author{
FRANTIŠEK RUT TICHÝ - WYBITNY KRZEWICIEL \\ JĘZYKA I LITERATURY BIAŁORUSKIEJ OKRESU MIĘDZYWOJENNEGO \\ W CZECHOSŁOWACJI
}

Imię Františka Rut Tichý'ego (1886-1968), pseudonim Zdeněk Broman, który zajmował się tłumaczeniem na język czeski (głównie poezji) z niemieckiego, francuskiego i języków słowiańskich, bardzo dobrze znali przedstawiciele kręgów naukowych germanistów, bohemistów i slawistów. Obecnie zarówno tłumacz, jak i jego działalność należą do osiągnięć zapomnianych krzewicieli kultury słowiańskiej żyjących i pracujących w pierwszej połowie XX wieku. Autor artykułu omawia działalność Tichy'ego związaną z czeskimi badaniami białorutenistycznymi w okresie międzywojennym (niektóre z nich dotyczą okresu po 1945 roku), zwłaszcza w zakresie tłumaczeń literatury białoruskiej na język czeski (Yanka Kupala, Aleś Dudar, Arkadź Morkavka, Cishka Gartny). Po raz pierwszy opublikowano pełną bibliografię tłumaczeń Tichy'ego z języka białoruskiego (tłumaczenia zachowały się w prywatnych zbiorach archiwum literackiego Muzeum Piśmiennictwa Narodowego Pradze).

Słowa kluczowe: czesko-białoruskie kontakty literackie, poezja białoruska, opowiadania białoruskie, tłumaczenie artystyczne, czeska białorutenistyka, cenzura, dokumenty archiwalne, percepcja literatury.

\title{
S U M M A R Y
}

\section{FRANTISHEK RUT TIHI - A DISTINGUISHED PROPAGATOR \\ OF THE BELARUSIAN LANGUAGE AND LITERATURE IN THE INTERWAR PERIOD IN CZECHOSLOVAKIA}

The name of Frantishek Rut Tihi (1886-1968) who gave himself the pseudonym Zdenek Broman was well known by German specialists, Czech specialists and Slavists. He was engaged in translations from German, French and the Slavonic languages into the Czech language (poetry mostly). Nowadays the author and his activity belong to the feats of forgotten propagators of Slavonic cultures who lived and worked in the first half of the 20th century. The article discusses his work devoted to Belarusian studies carried by Czech scholars in the interwar period (with some exceptions after 1945), especially the translations of the Belarusian literature 
into the Czech language (Yanka Kupala, Ales Dudar, Arkady Morkavka, Cishka Gartny). The bibliography of all Tihi's translations from the Belarusian language has been published for the first time (translations have been preserved in his private resources in literary archives in Památníku národního písemnictví in Prague).

Key words: Czech-Belarusian literary contacts, Belarusian poetry, Belarusian story, artistic translation, Czech studies of Belarusian literature, censorship, archival documents, literature perception. 